U.S. DEPARTMENT OF THE INTERIOR

GEOLOGICAL SURVEY

\title{
PRELIMINARY INTERPRETATION OF THE HIGH-RESOLUTION SEISMIC STRATIGRAPHY BENEATH LAKE MICHIGAN
}

David S. Foster and Steven M. Colman

U.S. Geological Survey

Woods Hole, MA 02543

Open-File Report 91-21

January 22, 1991

This report is preliminary and has not been reviewed for conformity with U.S. Geological Survey editorial standards and stratigraphic nomenclature. Any use of trade names is for descriptive purposes only and does not imply endorsement by the U.S. Geological Survey. 


\section{CONTENTS}

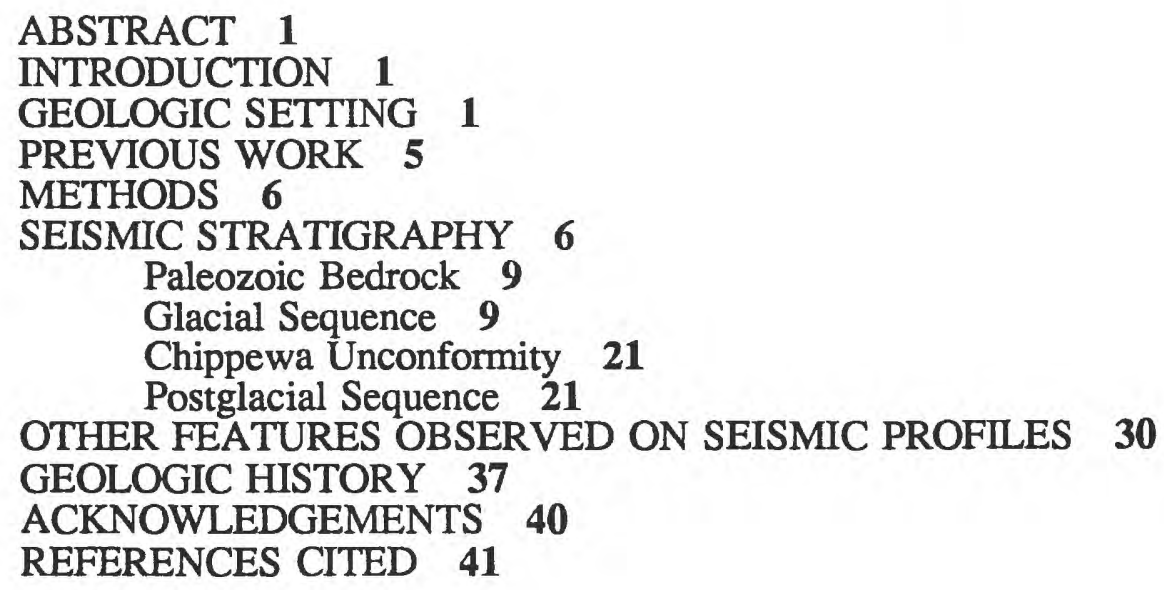

\section{FIGURES}

1. Map of Lake Michigan showing the location of seismic-reflection profile tracklines and figure locations 2

2. Bathymetric map of Lake Michigan 3

3. Quaternary stratigraphic columns for Lake Michigan 4

4. Seismic stratigraphic column for the nearshore, basin slope, and deep basin of the Lake Michigan Formation 8

5. Key explaining symbols used on seismic profiles $\mathbf{1 0}$

6. Seismic profile (Geopulse) showing reflection within bedrock; Shorewood till margin; Chippewa unconformity 11

7. Seismic profile $(3.5 \mathrm{kHz})$ showing bedrock highs in the southern basin $\mathbf{1 2}$

8. Seismic profile $(3.5 \mathrm{kHz})$ showing bedrock highs in the northern basin 13

9. Seismic profile (Geopulse) showing bedrock cuestas 14

10. Map showing the southern extent of till margins 15

11. Seismic profile $(3.5 \mathrm{kHz})$ showing the Shorewood till margin and the Chippewa unconformity 16

12. Seismic profile $(3.5 \mathrm{kHz})$ showing the Shorewood till margin and sublacustrine outwash 17

13. Seismic profile $(3.5 \mathrm{kHz})$ showing the Manitowoc till margin and lateral facies changes 18

14. Seismic profile $(3.5 \mathrm{kHz})$ showing a wedge of Two Rivers till 19

15. Seismic profile $(3.5 \mathrm{kHz})$ a moraine at the Manitowoc till margin 20

16. Seismic profile $(3.5 \mathrm{kHz})$ showing seismic-facies of the lower Lake Michigan Formation 22

17. Seismic profile $(3.5 \mathrm{kHz})$ showing truncation of the lower Lake Michigan Formation and the Chippewa unconformity 23

18. Seismic profile $(3.5 \mathrm{kHz})$ from the center of the southern basin 24

19. Map showing thickness and distribution of postglacial lacustrine deposits beneath Lake Michigan 25

20. Seismic profile (Geopulse) showing a thick wedge of the upper Lake Michigan Formation 27

21. Seismic profile $(3.5 \mathrm{kHz})$ showing the nearshore pinch out of the upper Lake Michigan Formation and nearshore sand wedge 28

22. Seismic profile $(3.5 \mathrm{kHz})$ showing sand capping till ridges 29

23. Seismic profile $(3.5 \mathrm{kHz})$ showing a scarp in Wadsworth till and a paleochannel 31 
24. Seismic profile $(3.5 \mathrm{kHz})$ showing scarp in Two Rivers till 32

25. Seismic profile (3.5 KHz) showing scarp in Wadsworth till onlapped by a wedge of the upper Lake Michigan Formation 33

26. Seismic profile $(3.5 \mathrm{kHz})$ showing a wedge of the upper Lake Michigan Formation backed by Paleozoic bedrock 34

27. Seismic profile $(3.5 \mathrm{kHz})$ showing a series of asymmetric ridges 35

28. Seismic profiles ( $3.5 \mathrm{kHz}$ and Geopulse) showing the Grand River Paleodelta and paleochannels 36

\section{TABLE}

1. Summary of seismic sequences, sequence boundaries, and facies characteristics 7

\section{PLATES}

1. Generalized south to north geologic section

2. Generalized west to east geologic section 


\begin{abstract}
High-resolution seismic-reflection profiles collected in the southern twothirds of Lake Michigan reveal seismic sequences and facies units that depict the late Quaternary glacial and postglacial stratigraphy under the lake. The late Wisconsinan glacial sequence lies unconformably above Paleozoic bedrock. Seismic facies analysis of the glacial sequence delineates till, ice-proximal and icedistal sublacustrine outwash, and glaciolacustrine facies. Lateral transitions in acoustic character between these facies suggest co-deposition of units. Till margins beneath the lake indicate the position of glacial readvances that coincided with higher-than-present lake levels. Evidence of low glacial lakes is not well preserved in the seismic stratigraphy. The only clear evidence of an extensive low lake level is an unconformity associated with the Chippewa low lake level (about $10 \mathrm{ka}$ ) which is represented by a seismic reflection (R2). The unconformity truncates the glacial seismic sequence on basin slopes and separates the glaciolacustrine unit of the lower Lake Michigan Formation from the postglacial lacustrine sequence of the upper Lake Michigan Formation. The reflection (R2) that marks the unconformity extends to the deep basins where the unconformity grades into an equivalent conformable horizon. The unconformity formed subaqueously during the transgression that followed the low Chippewa level, the pre-Nipissing transgression. Erosion during this transgression removed most paleochannels, deltas, beach deposits, wave-cut scarps, and ridges, as well as older unconformities that would indicate low glacial lake levels. The postglacial lacustrine sequence has an asymmetric distribution; as much as $18 \mathrm{~m}$ of postglacial deposits lie beneath the slope along the eastern side of the lake, whereas the western slope of the basin is underlain by deposits $4 \mathrm{~m}$ or less thick. Postglacial sediment is generally 2-4 m thick in the deep basins. Only thin patches of postglacial sediment and lag deposits veneer till over the southwestern end of the lake and over mid-lake bathymetric highs, suggesting these are regions of erosion and nondeposition.
\end{abstract}

\title{
INTRODUCTION
}

As part of a cooperative project with the states of Illinois and Indiana, the U.S. Geological Survey collected high-resolution seismic-reflection profiles and cores in the southern two-thirds of Lake Michigan in 1988 and 1989 (fig. 1).

Seismic sequence and facies analysis of high-resolution seismic-reflection profiles contribute basic information on the late Quaternary depositional and lakelevel history of the Lake Michigan basin. Oscillation of the Lake Michigan ice lobe margin and lake level have shaped the stratigraphy of till, sublacustrine outwash, and glaciolacustrine facies. An extreme low lake level marks the boundary between glacial and postglacial deposition. The depositional history of the lake basin over the last 10,000 years has shaped the thickness and distribution of Holocene deposits.

\section{GEOLOGIC SETTING}

The bathymetry of Lake Michigan defines several basins and bathymetric highs. The major southern and northern basins of the lake are separated by the mid-lake high, three smaller mid-lake basins, and a ridge, here referred to as the northern ridge (fig. 2). The three small mid-lake basins flank the mid-lake high to the east, west, and north. The northern ridge extends northeastward from the west side of the lake, separating the western and northern mid-lake basins from the much larger northern basin.

Glacial scouring of eastward dipping Paleozoic bedrock formed the overall basin morphology (Thwaites, 1949; Emery, 1951; Hough, 1958; Wickham and others, 1978). Soft shale underlies the deep basins, and resistant dolomite, limestone, and sandstone form ridges between the basins.

At least four till units (fig. 3b), the Wadsworth, Shorewood, Manitowoc, 


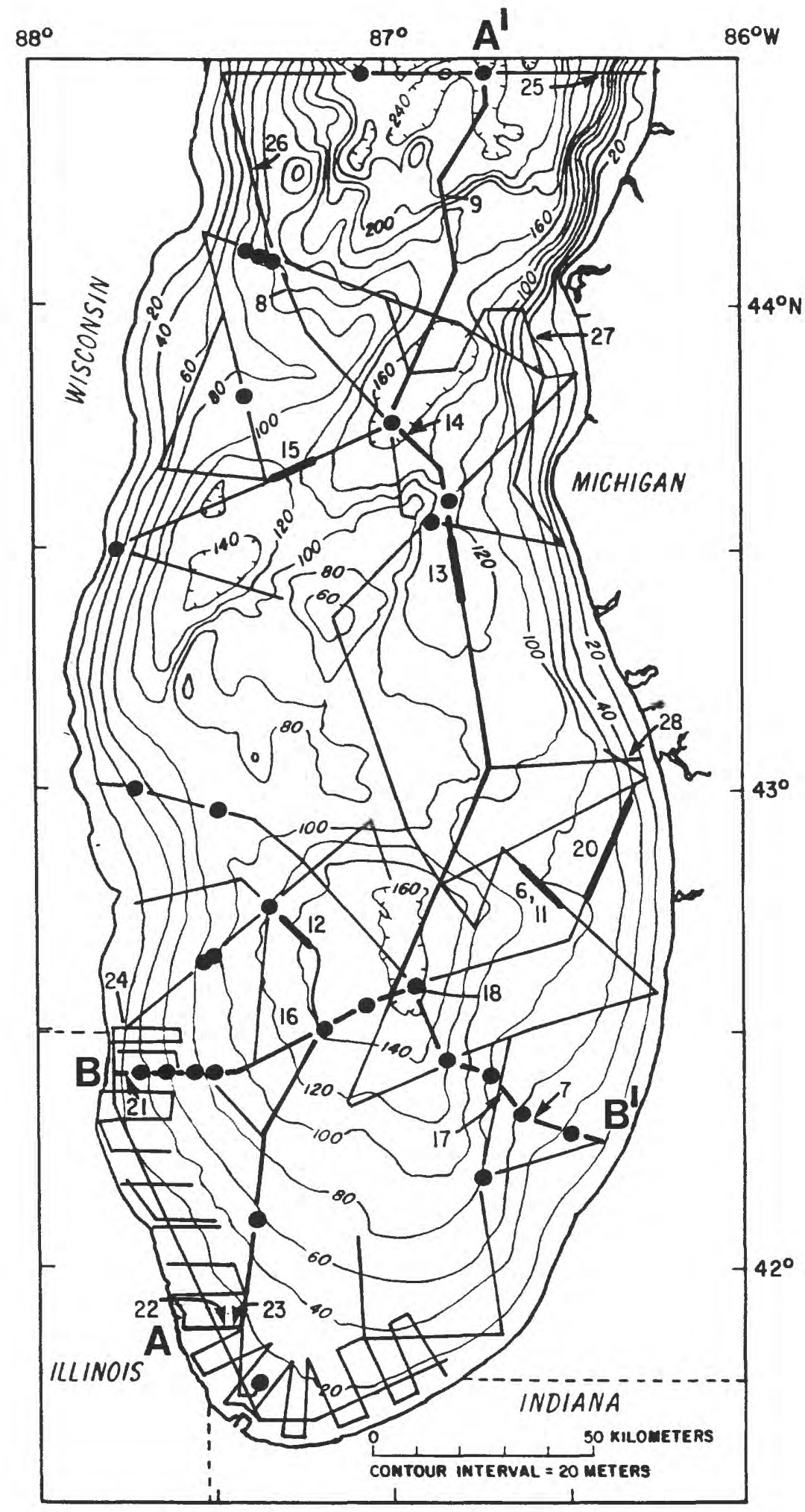

Figure 1. Map of Lake Michigan showing the location of seismic-reflection profile tracklines. Geologic sections in plates 1 (A-A') and 2 (B-B') are indicated with bold lines. Numbered thick line segments and arrows indicate locations of other figures. Solid circles show the location of cores described by Colman and Foster (1990). Bathymetric contour interval $20 \mathrm{~m}$. 


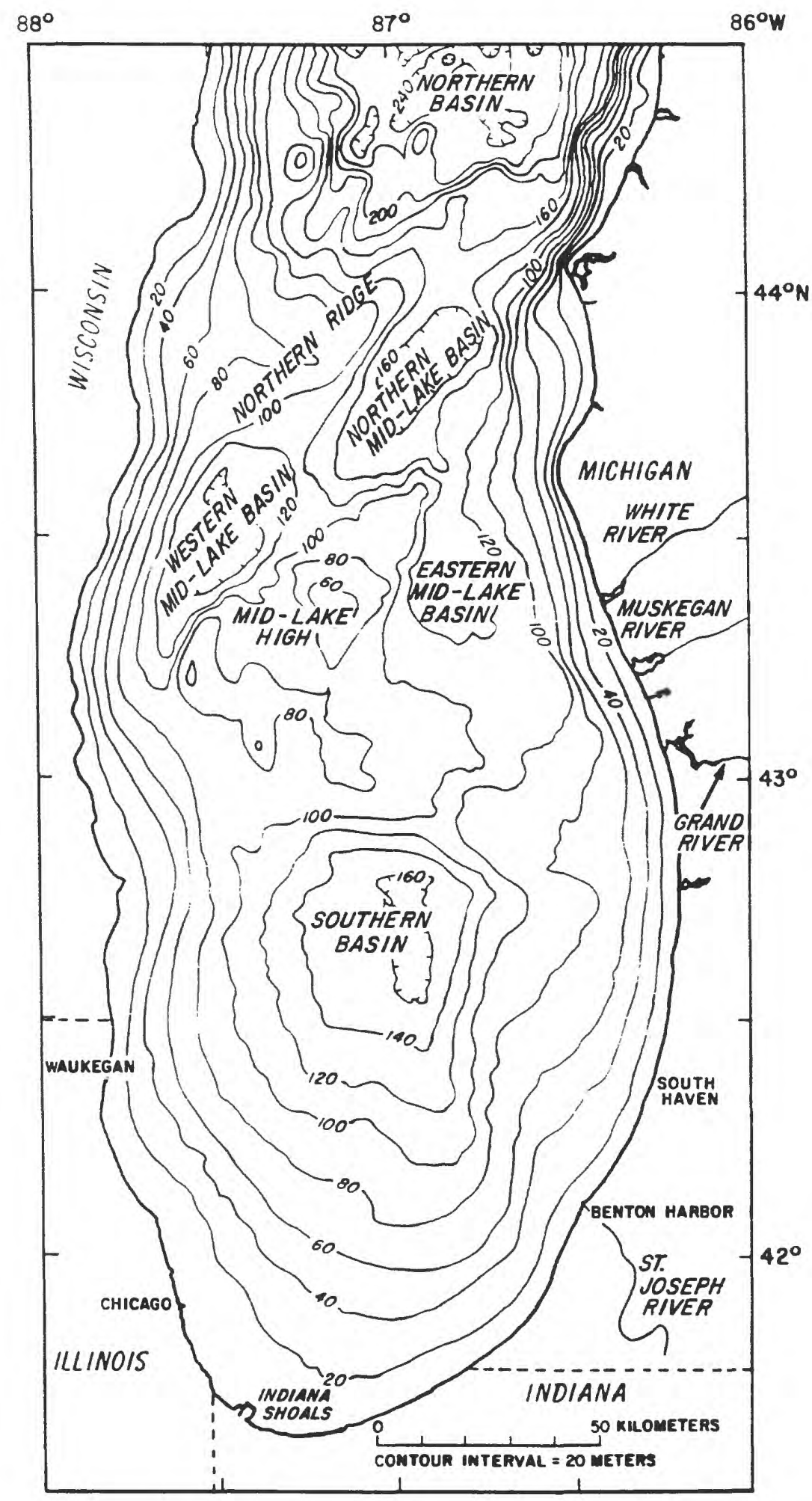

Figure 2. Bathymetric map of Lake Michigan showing the physiography of basins and topographic highs. Bathymetric contour interval $20 \mathrm{~m}$. 


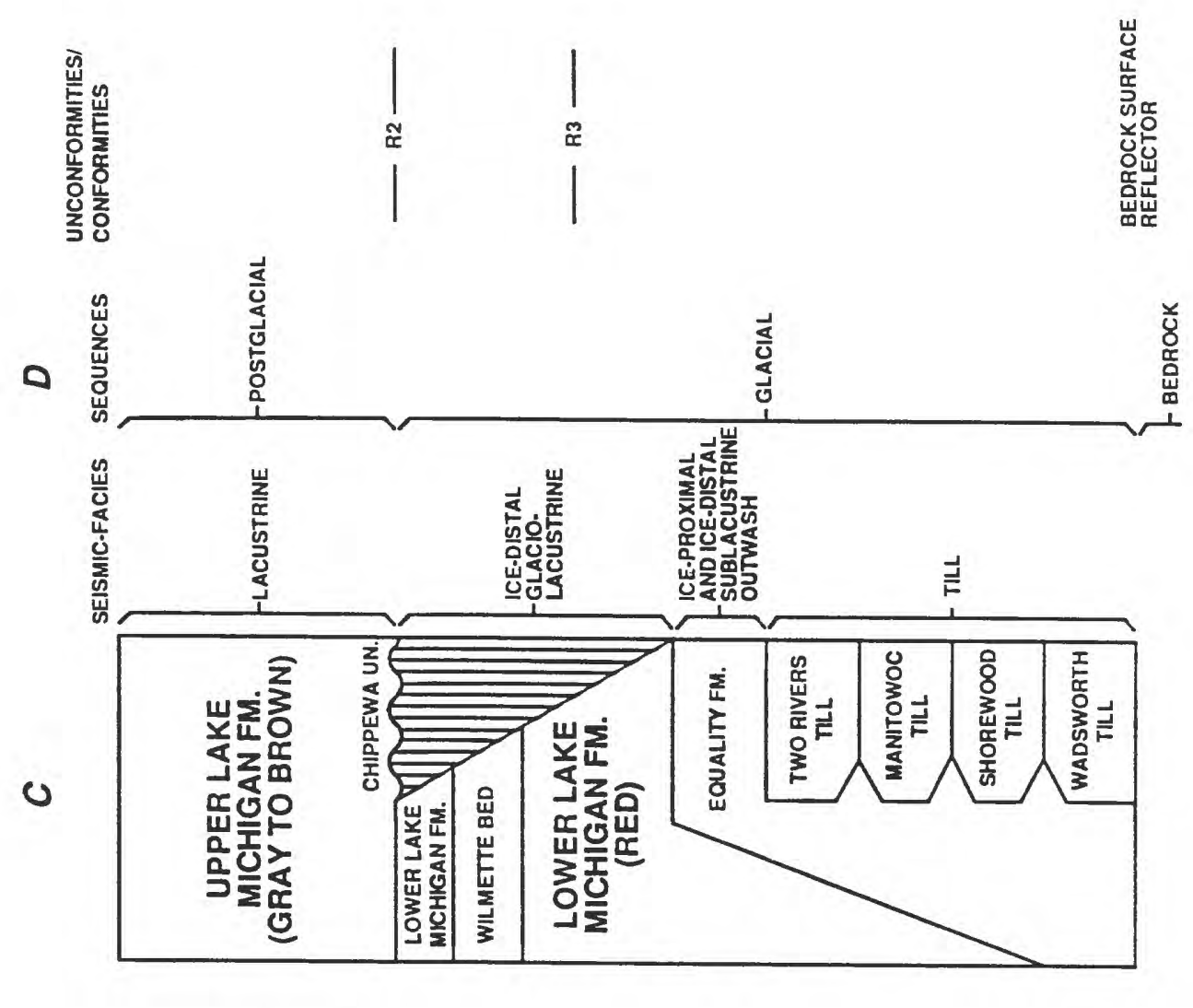

롤를

它

흥

包

영

๓

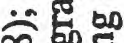

․․․

의.․․․

\%

몰.

论导

出余吉

न5 4

衰资

다옹

듕엉

봉

톨.

两

$<$.

元

总等馬

도으

근

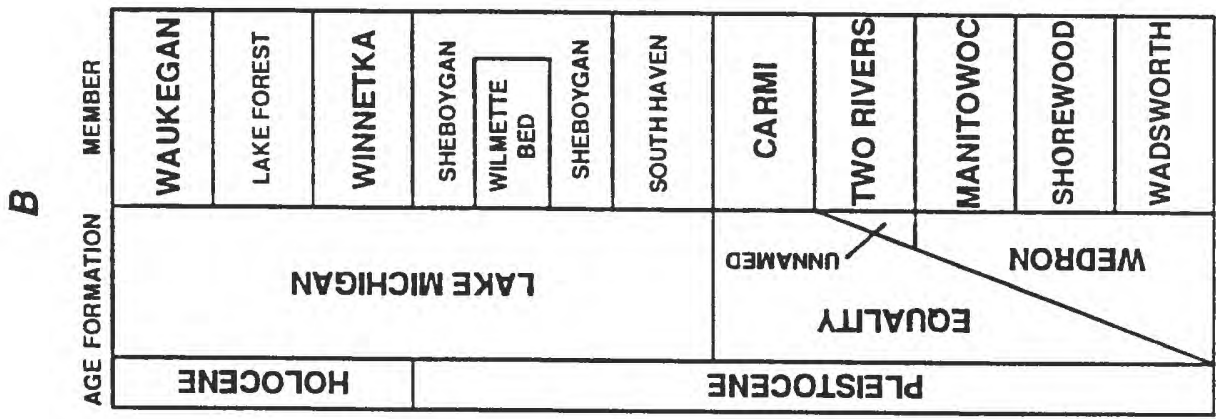

ขลํำ

ง

눙옹.

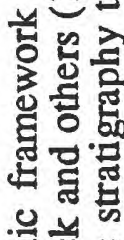

를.

5

品

붕ㅇ

守

긍응

르을

ة己.

的昆保

总

总 
and Two Rivers Members (Lineback and others, 1974), were deposited by late Wisconsinan glacial readvances during the overall retreat of the Lake Michigan ice lobe. Three minor glacial readvances are marked by moraines and (or) the distal margins of till wedges beneath Lake Michigan (Lineback and others, 1974). Readvances of the glacier incorporated proglacial lake deposits into till, as is supported by the predominantly silty clay lithology of cores that sample the till units (Lineback and others, 1974; Colman and Foster, 1990).

Ice advance and deposition of the till units coincided with high glacial lake levels (Hansel and others, 1985). The Wadsworth till was deposited during the Glenwood I level (14.5 and $13.5 \mathrm{ka}$ ), and the Shorewood and Manitowoc till were deposited during the Glenwood II level (13 and 12.2 ka). Both Glenwood levels reached about $19 \mathrm{~m}$ above present lake level. The slightly lower Calumet level (11.8 to $11.2 \mathrm{ka}$ ) was about $13 \mathrm{~m}$ above present lake level during the Two Rivers till readvance (Hansel and others, 1985, Larsen, 1985a,b).

Ice-proximal lacustrine sediment and outwash of the Equality Formation (Willman and Frye, 1970) (fig. 3b) was deposited over till primarily in the deep basins (Lineback and others, 1970). The Equality Formation is composed of sand, mud, and clay-pebble conglomerate, similar to the composition of the till unit from which it was derived (Gross and others, 1972).

Low lake levels coincided with glacial retreat and deposition of the Equality Formation (Wickham and others, 1978). The minimum elevations of low-level glacial lakes, the Intra-Glenwood low (13.5 to $13 \mathrm{ka})$ and the Two Creeks low (about $12 \mathrm{ka}$ ), are not well known (Hansel and others, 1985).

Red glaciolacustrine clay of the Sheboygan and South Haven Members (Lineback and others, 1970), the lower part of the Lake Michigan Formation (fig. $3 b$ ), was deposited beginning with the glacial retreat from the Two Rivers till margin, according to Wickham and others (1978) and Lineback and others (1979). As the glacier retreated from the Lake Michigan basin, the Straits of Mackinac were opened about $11.2 \mathrm{ka}$, and lake level dropped from the high Calumet level to the Main Algonquin of Michigan level, about $115 \mathrm{~m}$ below present lake level in the southern basin (Larsen, 1987). Deposition of the gray Wilmette bed interrupted red clay deposition within the Sheboygan Member.

A significant unconformity within the Lake Michigan Formation (fig. 3a) separates underlying red glaciolacustrine deposits from overlying gray postglacial deposits. Hough (1955) suggested that this unconformity formed with the fall of lake level to as much as $107 \mathrm{~m}$ below present lake level, the Chippewa low level. Drainage to the low Chippewa level occurred when an isostatically depressed northern outlet near North Bay, Ontario was deglaciated (Hough, 1955) about 10.3 ka (Larsen, 1987), thus the unconformity occurs approximately at the PleistoceneHolocene boundary.

The upper part of the Lake Michigan Formation (fig $2 b$ ), comprised of gray postglacial lacustrine clay of the Waukegan, Lake Forest, and Winnetka Members (Lineback and others, 1970), was deposited above the Chippewa unconformity. Postglacial deposition continued as isostatic rebound of northern outlet caused lake level to rise from the Chippewa low level to the Nipissing high levels ( 5 to $4 \mathrm{ka}$ ) that were up to $8 \mathrm{~m}$ above present lake level. Lake level then fell to the Algoma level and continued to fall, reaching modern lake levels at $2.5 \mathrm{ka}$ (Hansel and others, 1985).

\section{PREVIOUS WORK}

The Illinois State Geological Survey (ISGS) collected $3000 \mathrm{~km}$ of 3.5 and 7-kHz seismic profiles (Lineback and others, 1971, 1974; Gross and others, 1972; Lineback and Gross, 1972) and $5140 \mathrm{~km}$ of $14.25-\mathrm{kHz}$ echosounder profiles (Wickham and others, 1978) from Lake Michigan. The high-frequency profiling systems used in these studies had limited penetration in till and did not always penetrate lacustrine sediment in sandy nearshore areas or where seismic signals were attenuated by gas-bearing sediment. Previous seismic stratigraphic 
interpretations were correlated with the stratigraphic nomenclature proposed by Lineback and others (1970), which was based on sediment cores (fig. 3b).

\section{METHODS}

High-resolution seismic-reflection profiles and cores from 29 sites (Colman and Foster, 1990) were collected in the southern two-thirds of Lake Michigan (fig. 1). The data were collected aboard the RV Roger B. Simons in September, 1988, along $950 \mathrm{~km}$ of tracklines, and aboard the RV Laurentian in June, 1989, along $1250 \mathrm{~km}$ of tracklines. An additional $700 \mathrm{~km}$ of seismic profiles were collected along the Illinois and Indiana nearshore zone in July and August, 1988, aboard the RV Neecho, and in May, 1989, aboard the RV Neptune. Tracklines were navigated with a Megapulse Accufix 500 Loran C receiver or a Miniranger System. Two types of seismic profiling systems were used: 1) an ORE 3.5-kHz system along seismic lines and during coring operations and 2) a boomer-type system, using a Huntec source ( 500 joules) or an ORE Geopulse source ( 280 joules). The boomers were triggered every $0.5 \mathrm{~s}$, and the seismic signals were filtered between 300 and $5000 \mathrm{~Hz}$. The $3.5-\mathrm{kHz}$ and boomer seismic profiles were typically recorded at a $0.25 \mathrm{~s}$ sweep rate.

Our interpretation of the Quaternary seismic stratigraphy of Lake Michigan followed the approach of Mitchum and others (1977a,b) which employs sequence and facies analysis. Seismic sequences are defined as packages of genetically related reflections bounded by unconformities or their equivalent conformable surfaces. Within seismic sequences, seismic-facies units have internal reflections and external form that differ from adjacent units. Facies parameters were interpreted to suggest depositional environment and lithology of the seismic units. Traditionally, seismic sequence analysis has not been applied to Quaternary seismic stratigraphy; however, any seismic unit that is bounded by discontinuities can be defined as a distinct depositional sequence, regardless of the geologic age of the unit. Our use of seismic sequences to describe glacial depositional units is not the same as morphosequences (Koteff and Pessl, 1981) used in describing subaerial glacial deposits.

Core descriptions from Hough $(1955,1958)$, Lineback and others (1970, 1971, 1972, 1974), Lineback and Gross (1972), Wickham and others (1978), and ISGS (unpublished data), together with cores collected in conjunction with this study (Colman and Foster, 1990), provided data for verification of the seismic stratigraphy.

\section{SEISMIC STRATIGRAPHY}

The shallow seismic stratigraphy beneath Lake Michigan is defined by seismic sequence and facies units. The acoustic properties and geometric relationships of seismic units are summarized in table 1 . This stratigraphy includes two distinct unconformities that separate three seismic sequences (fig. 3d). The sequences are: 1) Paleozoic bedrock; 2) late Wisconsinan glacial deposits; 3) postglacial lacustrine deposits. Although Paleozoic bedrock is a distinct seismic unit, we do not interpret the geologic history of bedrock in this report. However, the unconformity at the bedrock surface defines the lower boundary of the glacial sequence. The glacial and postglacial seismic sequences are divided into seismicfacies units (fig. 3d). The glacial sequence contains till, ice-proximal and ice-distal sublacustrine outwash, and glaciolacustrine units (table 1). The postglacial sequence consists entirely of lacustrine deposits that grade from nearshore sand to deep basin mud facies. A thick wedge of lacustrine sediment on the eastern slope of the lake comprises a distinct facies unit of the postglacial sequence (table 1).

We attempted to correlate our seismic units with the stratigraphic nomenclature that was derived from lithostratigraphy from cores (fig. 3b) (Lineback and others, 1970). However, this correlation is sometimes awkward. The unconformity (R2, fig. 4) that separates the glacial and the postglacial seismic 


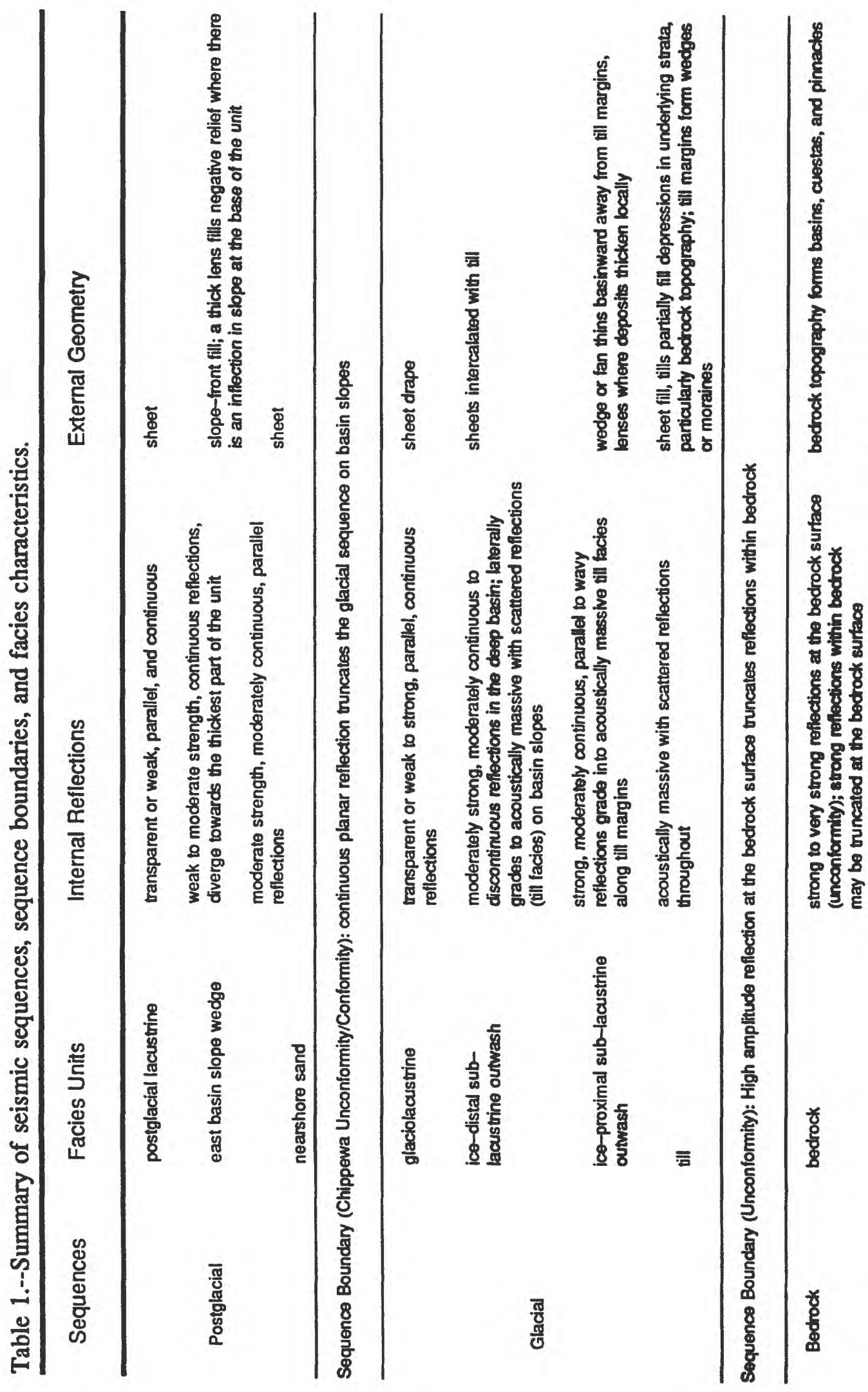




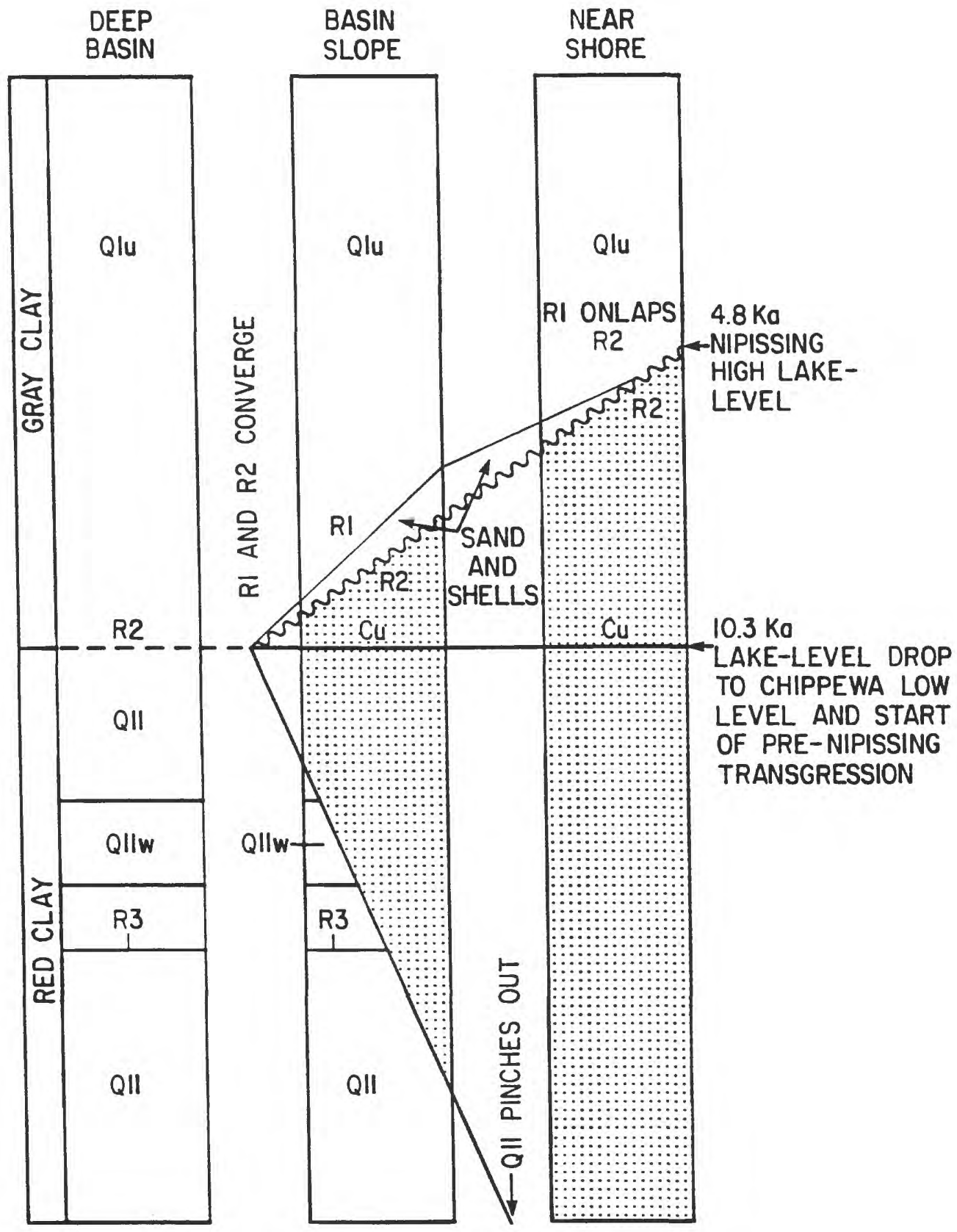

Figure 4. Seismic stratigraphy for the nearshore, basin slope, and deep basin of the Lake Michigan Formation; Qlu, upper Lake Michigan Formation (postglacial sequence); Q1l, lower Lake Michigan Formation (upper part of the glacial sequence). Stipple pattern indicates deposits are absent. Seismicreflections R1, facies change within the upper Lake Michigan Formation; R2, Chippewa transgressive unconformity and conformity in the deep basins; $\mathrm{Cu}$, inferred regressive Chippewa unconformity which is not observed on seismic profiles; R3, reflection within the lower Lake Michigan Formation. 
sequences occurs within the Lake Michigan Formation (fig. 3b). We informally use the terms "lower Lake Michigan Formation" (part of the glacial sequence) and "upper Lake Michigan Formation" (postglacial sequence), which are separated by an unconformity. Another problem in using the previous nomenclature occurs where glaciolacustrine, sublacustrine outwash, and till facies were designated as formations. These facies commonly grade into each other and outwash commonly lies between till units, suggesting that the formation status designated to glacial units by Lineback and others (1970) is inappropriate. Two formations, corresponding to the glacial and postglacial seismic sequences, would be more appropriate, but we have retained the nomenclature of Lineback and others (1970) as much as possible for simplicity.

\section{Paleozoic Bedrock}

The bedrock surface usually appears as a relatively high-amplitude reflection on the boomer-type seismic profiles (figs. 5 and 6). The gross morphology of the lake basin conforms to the bedrock surface. In places, bedrock highs crop out at the lake floor in the southern basin (fig. 7), but local bedrock relief is most often buried by sediment. Bedrock highs and ridges are common near the lake floor in the northern basin (fig. 8) where the more complex bathymetry reflects the bedrock topography (fig. 2). Bedrock ridges that trend northeast form the mid-lake high and northern ridge are prominent on the seismic profiles (fig. 9).

\section{Glacial Sequence}

We interpret thick, acoustically massive seismic-facies that contain scattered, incoherent reflections as tills (table 1). The upper parts of the tills, sampled by cores, consist primarily of silty clay with lesser amounts of sand and pebbles; the tills have been correlated to onshore units (Lineback and others, 1974; Colman and Foster, 1990). The relationships among the tills are illustrated in a geologic section constructed from the seismic profiles (plate 1) and a map showing the southern extent of the till margins (fig. 10). The Wadsworth till (Qww) and an older till unit (Qwu), possibly Haeger till, were deposited by readvances that terminated south of the current lake basin. The Shorewood till (Qws), Manitowoc till (Qwm), and Two Rivers till (Qtr) have distinct margins at their southern limits, where the ice margin readvanced and terminated in the lake basin. The till margins form wedges (figs. 6 and 11-14) or moraines (fig. 15) which pinch out (figs. $6,11,14$, and 15) or grade into stratified, ice-proximal, sublacustrine outwash (figs. 12 and 13). A previously unidentified till unit (Qwu) is older than Two Rivers till and appears to wedge out above Manitowoc till (figs. 10 and plate 1). This till may represent a distinct readvance, but it may also be an isolated occurrence of one of the pre-Two Rivers tills.

Ice-proximal, sublacustrine outwash (Qeo) is a facies (table 1) that was deposited proximal to till margins. In places, ice-proximal, sublacustrine outwash grades laterally into till at till margins (figs. 12 and 13). In the southern basin, the outwash forms a fan shaped deposit that thins away from the Shorewood till margin (fig. 10). We include this facies as part of the Equality Formation of Lineback and others (1970).

In the deep basins, a stratified seismic-facies unit (Qe) with moderately continuous to discontinuous reflections (table 1 ) is intercalated with the till units (figs. 11-15). The stratified unit can be traced between till units for distances as much as $30 \mathrm{~km}$ north of the till margins (plate 1), before it is lost on the seismic profiles due to lack of acoustic penetration on the $3.5-\mathrm{kHz}$ profiles and poor resolution on the boomer-type profiles. On the basin slopes internal reflections become discontinuous and weak. Towards the till, the unit becomes acoustically massive, similar to till, making the contact between lacustrine deposits and till a transitional one (fig. 13). We identify this facies unit as ice-distal sublacustrine outwash, correlative with the Equality Formation of Lineback and others (1970). 


\section{SEISMIC UNITS}

Qlu

QII

Qe

Qeo

Qtr

Qwm

Qws

Qww

Qwu

Pz

p

2

UPPER LAKE MICHIGAN FORMATION (POSTGLACIAL SEISMIC SEQUENCE)

LOWER LAKE MICHIGAN FORMATION (GLACIOLACUSTRINE FACIES OF THE GLACIAL SEISMIC SEQUENCE)

EQUALITY FORMATION (ICE-DISTAL SUBLACUSTRINE OUTWASH FACIES OF THE GLACIAL SEISMIC SEQUENCE)

EQUALITY FORMATION (ICE-PROXIMAL SUBLACUSTRINE OUTWASH FACIES OF THE GLACIAL SEISMIC SEQUENCE

TWO RIVERS TILL MEMBER (TILL FACIES OF THE GLACIAL SEQUENCE)

MANITOWOC TILL MEMBER OF THE WEDRON FORMATION (TILL FACIES OF THE GLACIAL SEISMIC SEQUENCE)

SHOREWOOD TILL MEMBER OF THE WEDRON FORMATION (TILL FACIES OF THE GLACIAL SEISMIC SEQUENCE)

WADSWORTH TILL MEMBER OF THE WEDRON FORMATION (TILL FACIES OF THE GLACIAL SEISMIC SEQUENCE)

UNDIFFERENTIATED TILL (TILL FACIES OF THE GLACIAL SEISMIC SEQUENCE)

PALEOZOIC BEDROCK (BEDROCK SEISMIC SEQUENCE)

\section{SEISMIC REFLECTIONS}

R1 FACIES CHANGE WITHIN THE UPPER LAKE MICHIGAN FORMATION (POSTGLACIAL SEQUENCE)

R2 CHIPPEWA UNCONFORMITY OR THE EQUIVALENT CONFORMITY (GLACIAL POSTGLACIAL SEISMIC SEQUENCE BOUNDARY)

R3 MARKER REFLECTION WITHIN THE LOWER LAKE MICHIGAN FORMATION; POSSIBLE CONFORMITY THAT RELATES TO MAIN ALGONQUIN LOW LEVEL

HEAVY LINES ON LINE DRAWINGS ARE MAJOR UNIT BOUNDARIES; LIGHT LINES REPRESENT INTERNAL REFLECTIONS WITH A MAJOR UNIT

\section{ARTIFACTS}

M MULTIPLE REFLECTION

C CROSS-TALK INTERFERENCE

Figure 5. Key explaining symbols used for seismic profile figures. 
(SONOJZSIרาIW NI)

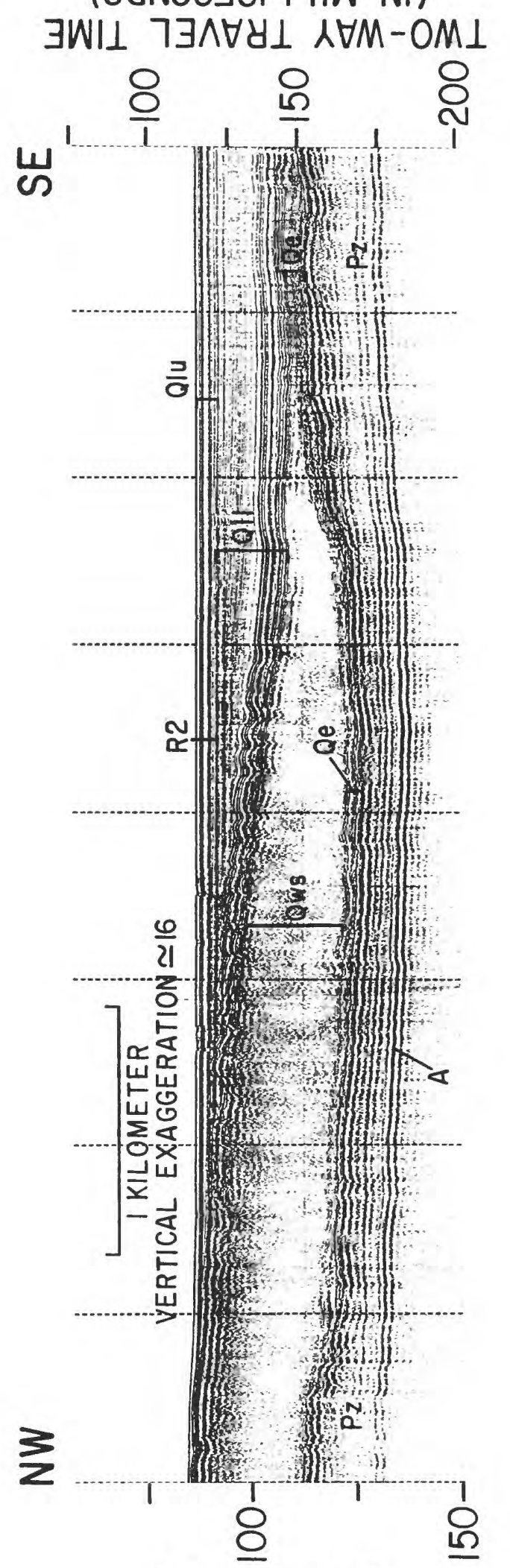

定举

능

응

.

层

్ㅠㄹㄹㅠ

\& …

莺

क是

늑 용

옹률

梂㟧

承芯

눙음

挐

능 듬

品

88

눈

㟧㟧

氠 들

눙

잉맘

대워 है

를

an 음묘

का ठ

\%

을 혼

วี

密

드의

运证

0 융

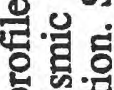

运. 웡

오월ㅇ

녕영

创宾

氜

ผ 돈

(S丩 $\exists \perp \exists W \mathrm{NI}$ )

密

$H \perp d \exists O \exists \perp \forall W I X O Y d d \forall$ 


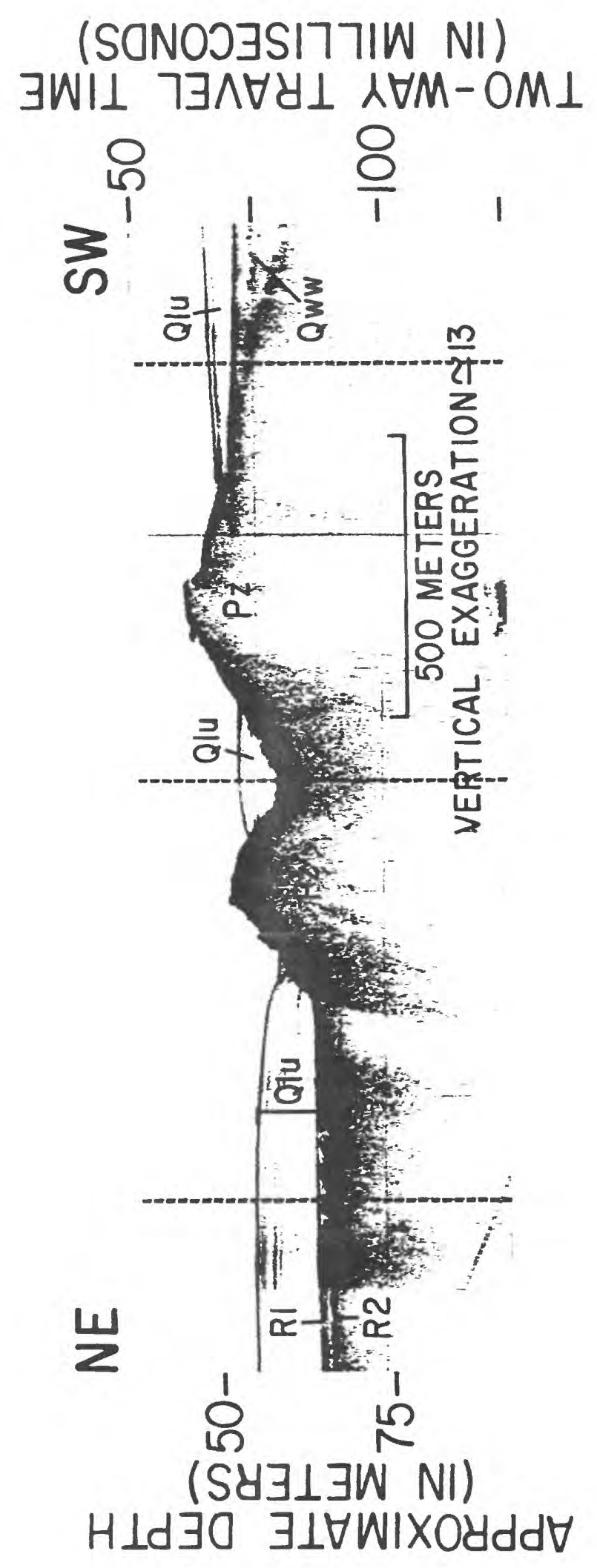

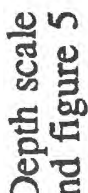

. 당

. 돌

ㅁํㅇ

E 8

氖

응-

巳

.돈

ర్요

o

흘

을

颍

ते

흐

000

脕

응.

ट्ट

.

는

녕

83

600

宩

혼

종

章

n

를

을

낭

a

ธ댕

을은

फ.으

듬

웡

ह

娄尔

드웅

总 


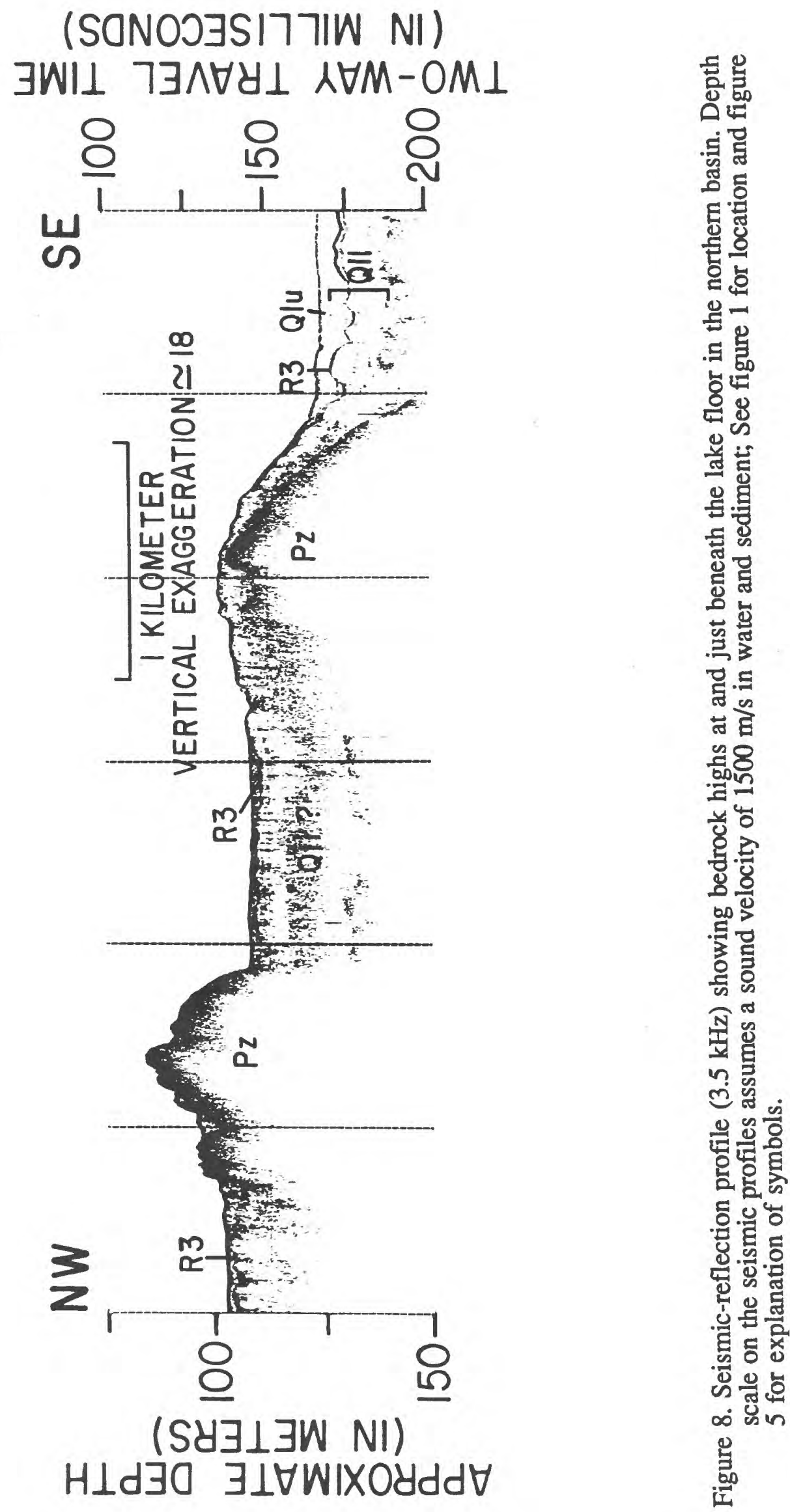




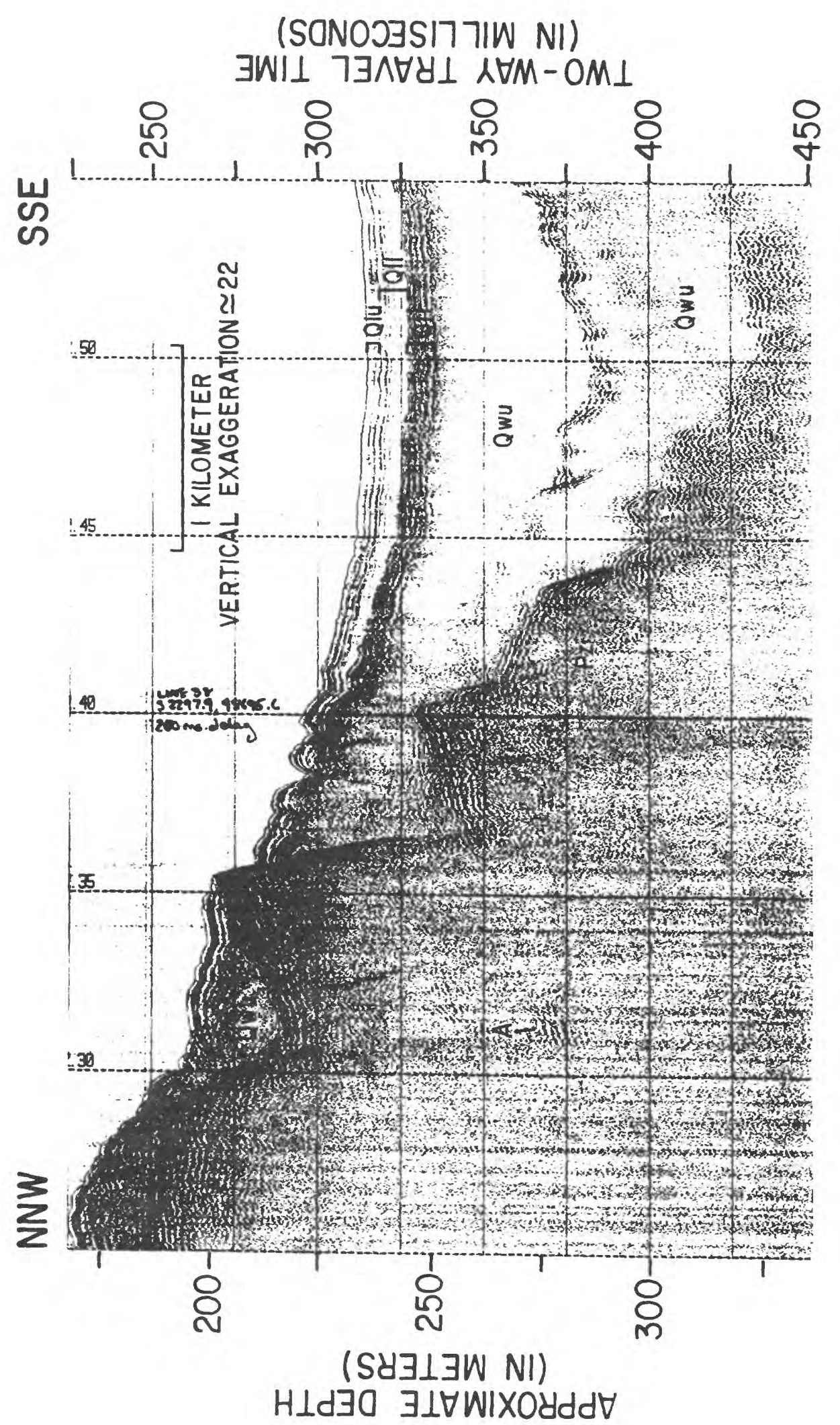

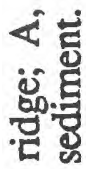

토음

E

다

음 है

튱ㅁำ

륭

a

들

.20

ซ

ક5

s:

월

卷起

녕명

๘.0

ㅇ․을

.

的它

จิธี 눈

羿的

O용

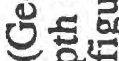

율

년

도웛

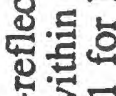

造

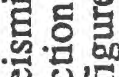

की

$\sigma 0$

点 


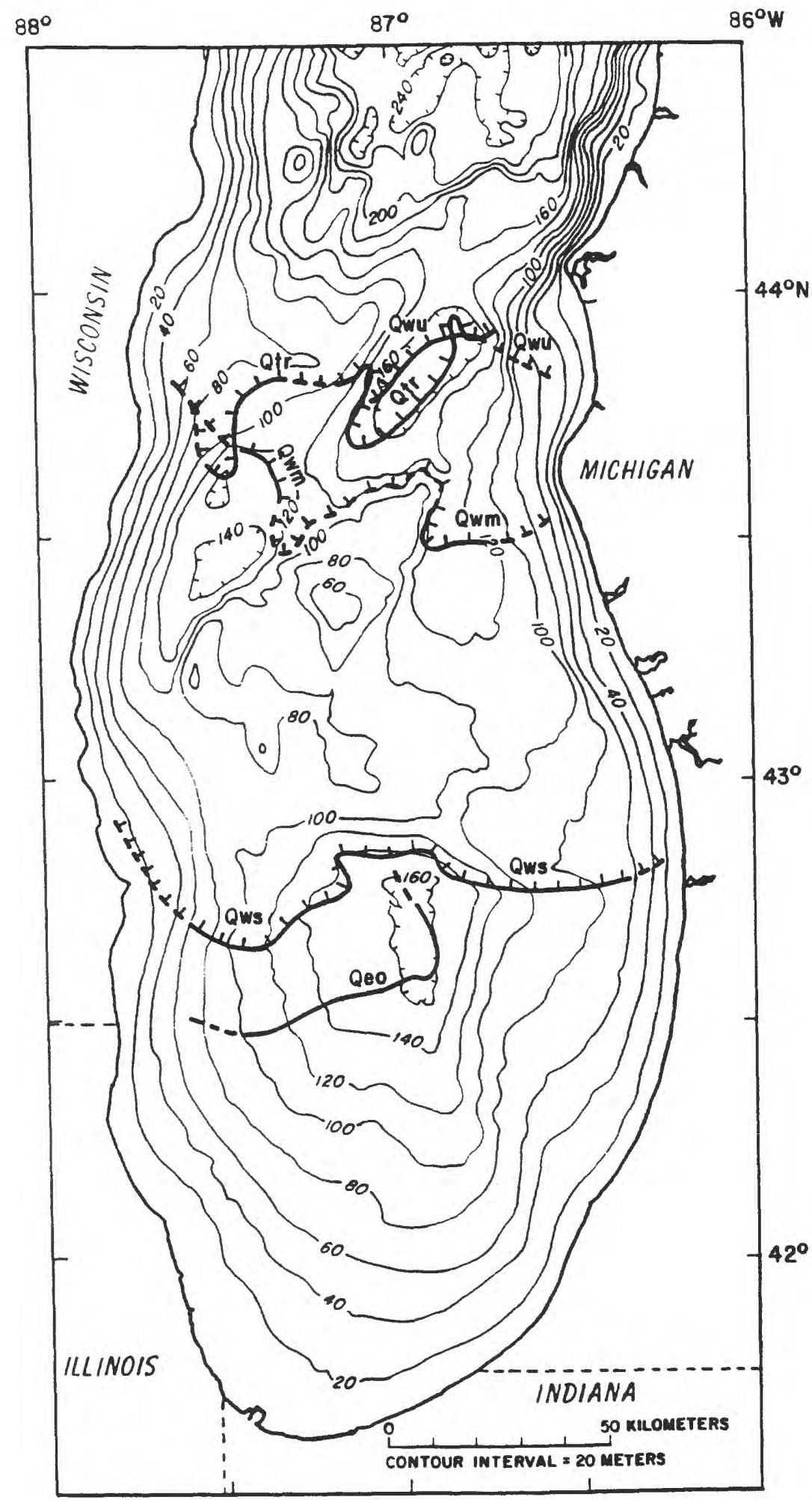

Figure 10. Map showing the southern extent of till margins and the margin of an extensive ice-proximal sublacustrine outwash deposit $(\mathrm{Q} e o)$ beneath Lake Michigan. Qws, Shorewood till margin; Qwm, Manitowoc till margin; Qwu, undifferentiated till margin within the Wedron Formation; Qtr, Two Rivers till margin. Hatures indicate the up-ice side of the margin. Margins are dashed where inferred. 


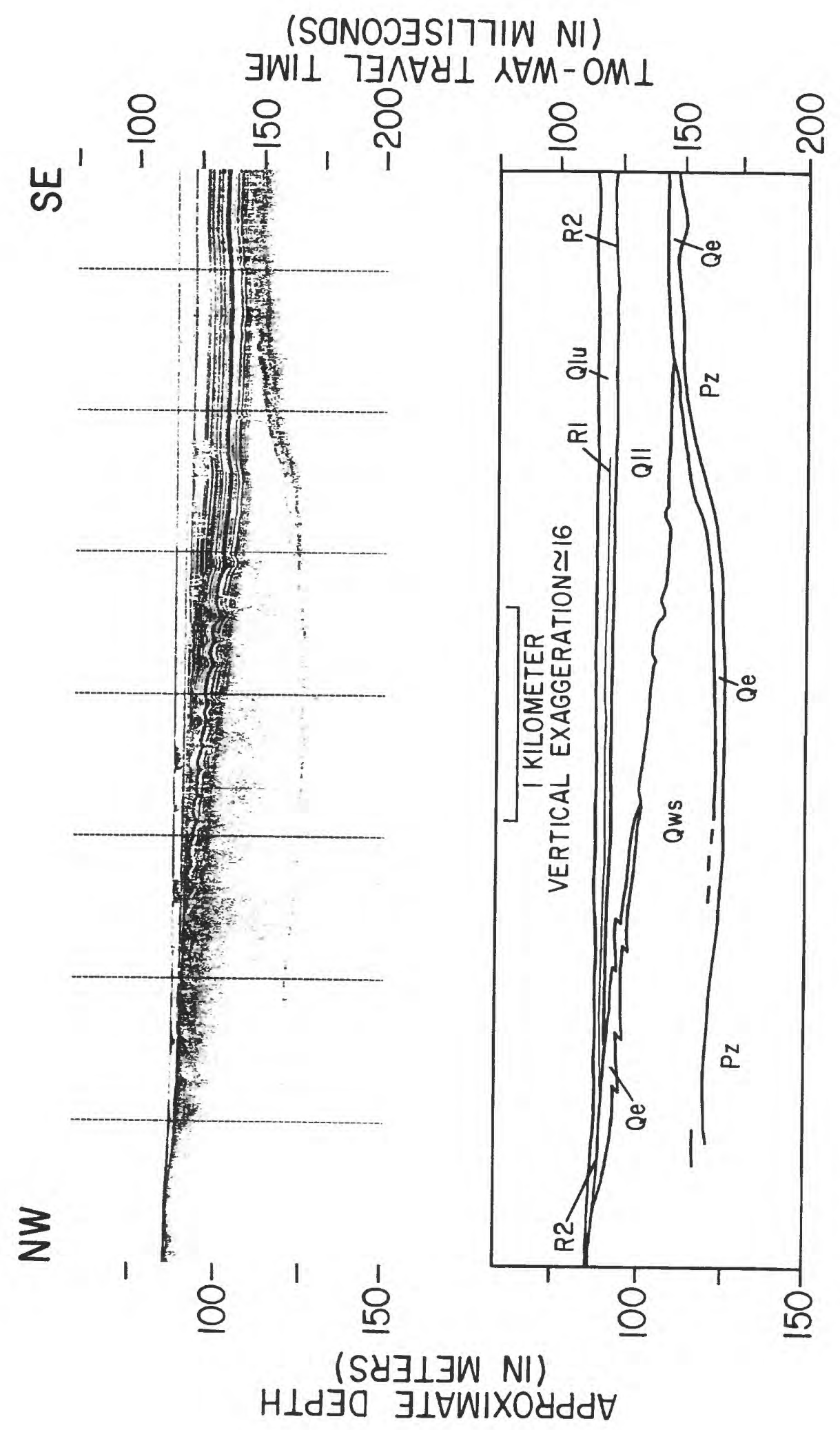

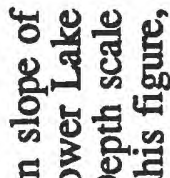

트응를

웡

递宫

홀를

등ㅎㅇㅇㄴㅇ

。苛

이돈

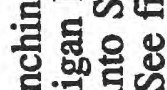

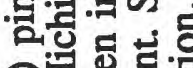

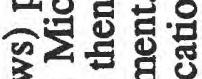

है

司尔乐里

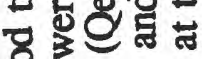

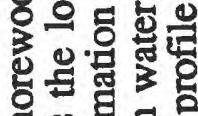

的题. 동

फั

品刍 8 영

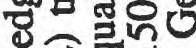

ब뚠후

60 证

产总总

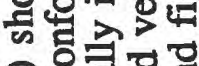

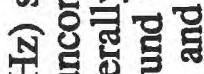

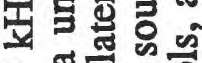

ก

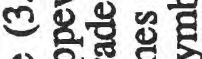

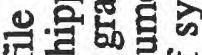

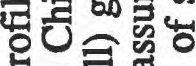

눌형.

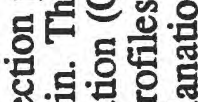

氙虽

4 동

峞

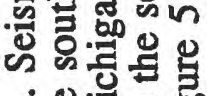
可车运吠嵒

总 


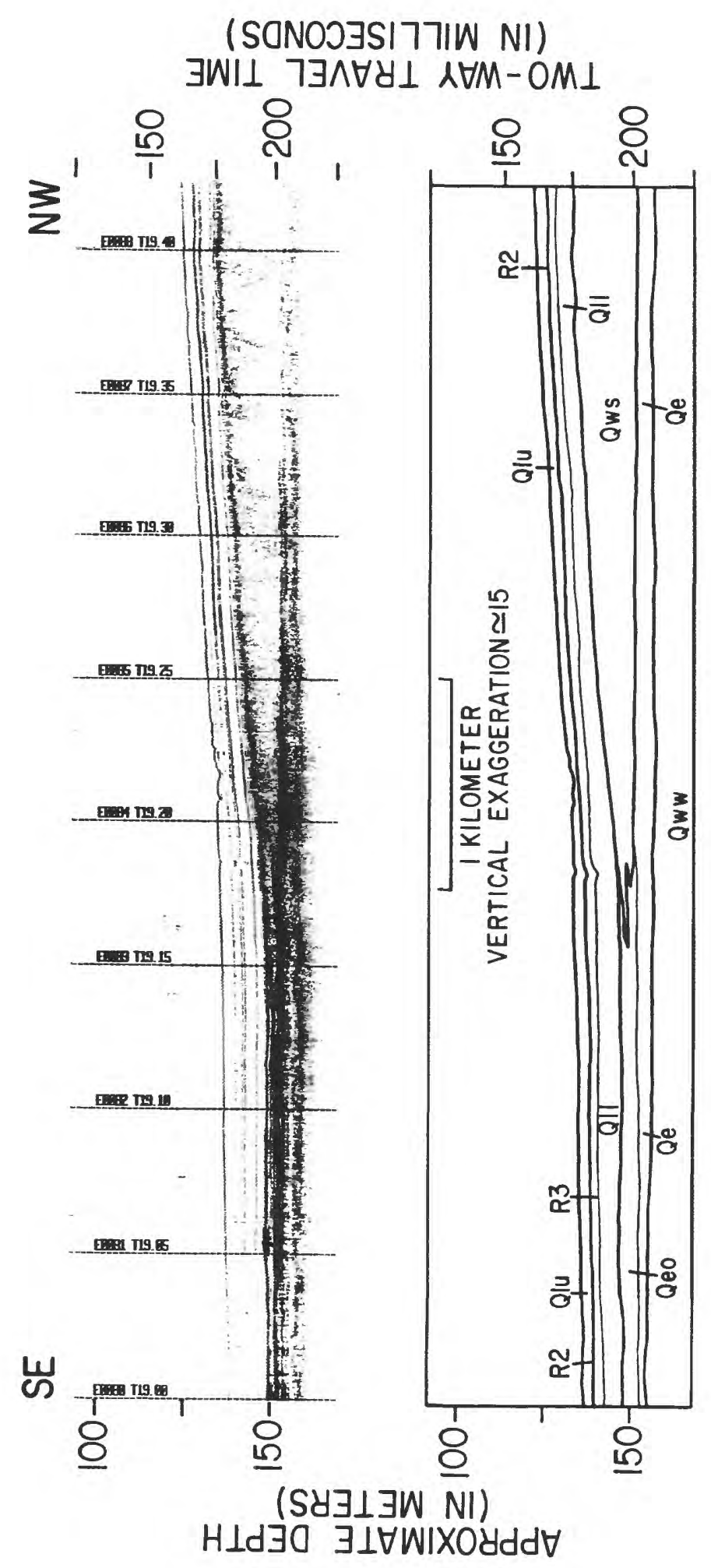

昜

를

สำ

牙

혼?

.0

8

몽

ชู

b

兘

两

领

逍

司这

응응

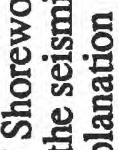

पै

웡

㣢的

을를

.

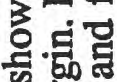

좀ํำ

空

n :

ल.

岂完

造

क 5

记

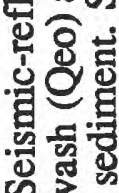

흘

总 


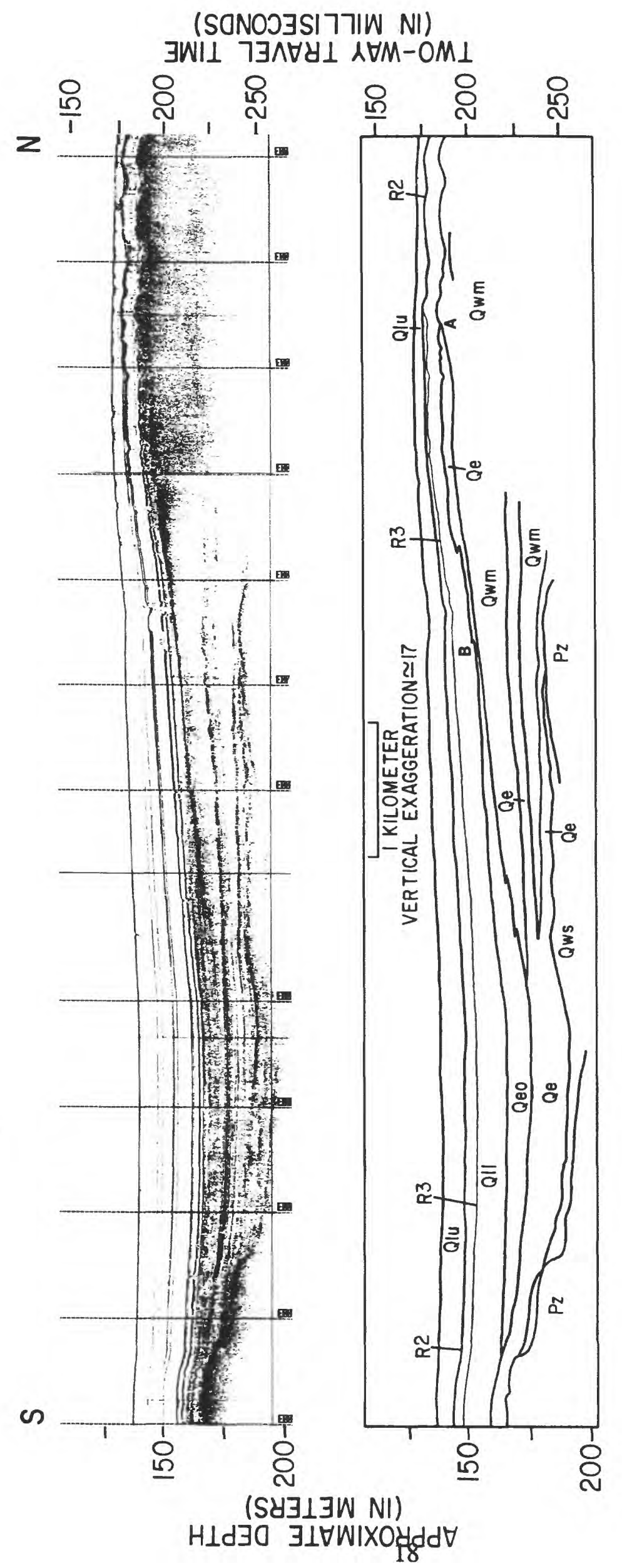

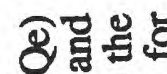
등 옹을 의

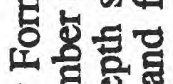
政 a

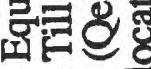

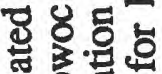
동 홀롤 골렬

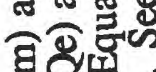
急然 司哲密 8 후를 证

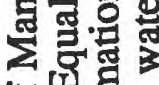

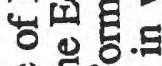
政识

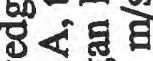

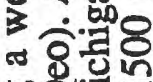
cood S.

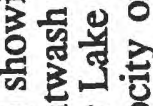

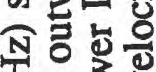
标 设影 열 태욤 c

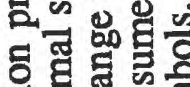
음도을 ș

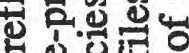
ㅇ․ 연 일

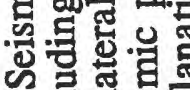

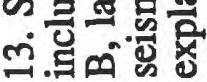
喜 


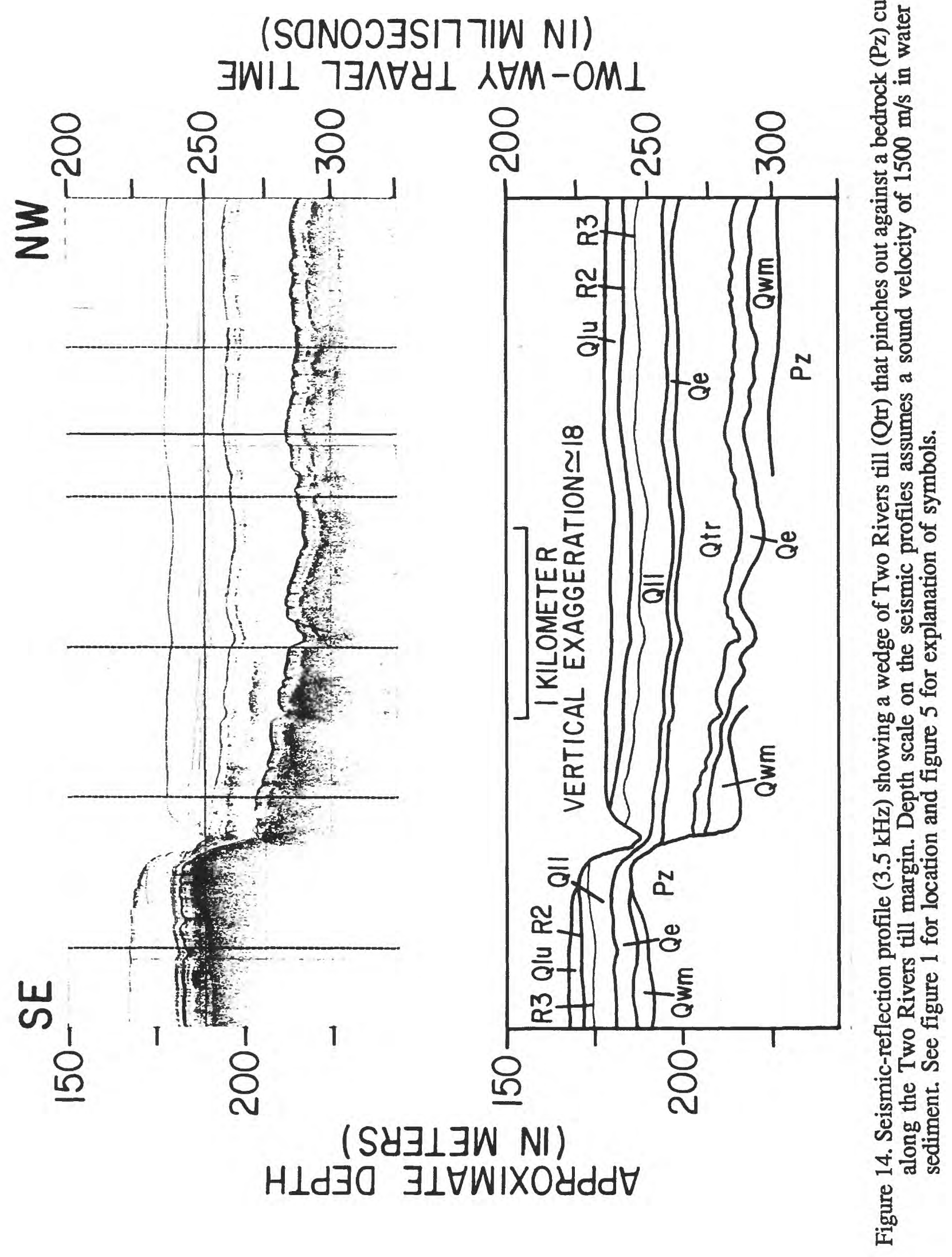




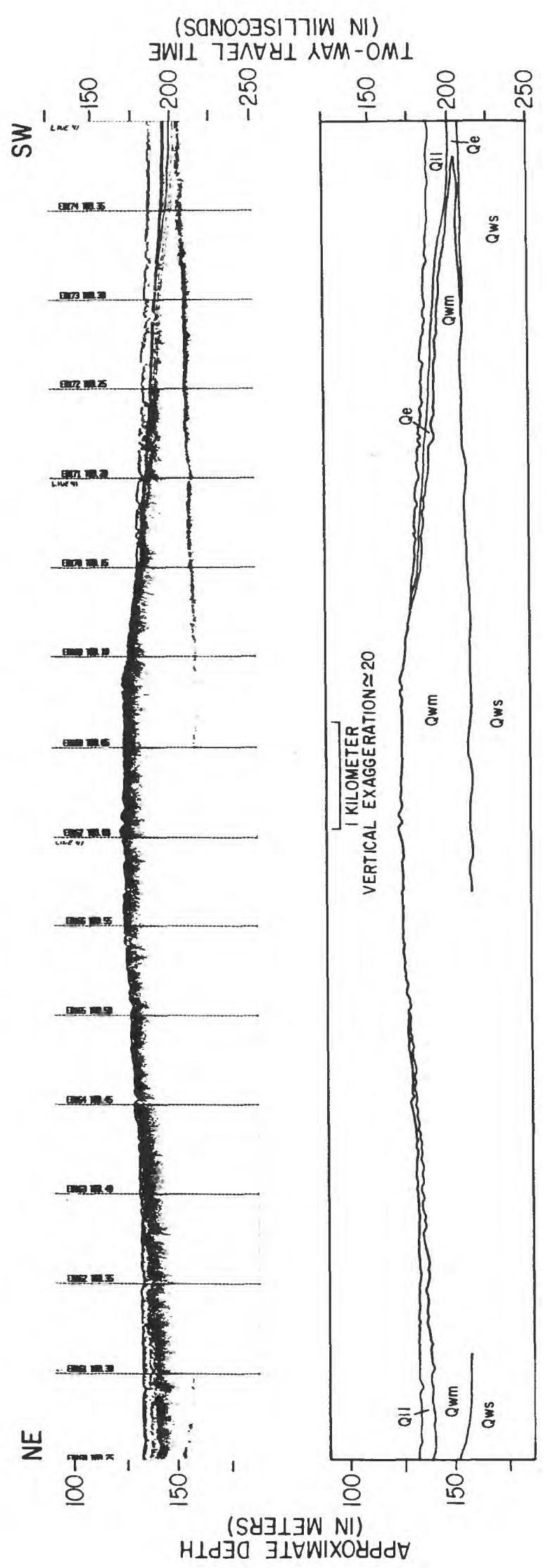

응

융

.

z

를

.5

옹형

5

.

60

承

घ음

ํㅡㄹ

를

包的

录.

8 붕.

今

灵毠

恼

운

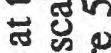

.

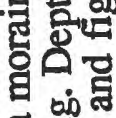

त.

55.

客

㲾

성

要.

ก

운

迄导

입쫀

.

을 동

过

क्ष

.

․ㅗㄹ율

政

ம்.

号

50 
Cores that penetrate the Equality Formation contain sandy clay with abundant clay and lithified clasts (Lineback and others, 1970; Wickham and others, 1978; Colman and Foster, 1990).

Overlying the Equality Formation (Qe), a distinct seismic-facies unit (Q1l) is acoustically transparent or contains weak to strong, continuous reflections that drape deeper seismic units (fig. 16). The unit (Q11) is thickest in the deep basins and is truncated by an unconformity on the basin slopes (fig. 17 and plate 2). In places, the continuous internal reflections at the base of this unit (Q11) grade laterally into stronger, moderately continuous to discontinuous reflections, similar to those of the sublacustrine outwash facies of the Equality Formation (Qe) (fig. 13). We informally call this unit (Q11) the lower Lake Michigan Formation and infer an ice-distal, glaciolacustrine origin. Cores that penetrate the lower Lake Michigan Formation contain extremely fine-grained reddish clay that is relatively uniform throughout the unit. Silt rhythmites and occasional beds of clay and lithified clasts have been observed in some cores (Wickham and others, 1978; Colman and Foster, 1990). The lower Lake Michigan Formation corresponds to the South Have and Sheboygan Members of Lineback and others (1970). Cores show a distinctive gray clay marker bed, the Wilmette Bed (Qllw), within the lower Lake Michigan Formation (Hough, 1955, 1958; Wickham and others, 1978; Colman and Foster, 1990).

A strong, continuous reflection (R3) within the lower Lake Michigan Formation (fig. 18) can be traced throughout individual basins and possibly throughout Lake Michigan. In places the reflection has a hummocky appearance where the lower Lake Michigan Formation drapes irregular surfaces on till and Equality Formation deposits (figs. 8, 13). The position of reflection R3 matches that of relatively coarse sandy silt zones in two cores from the southern basin slope (cores 19P and 20P, Colman and Foster 1990); however, this correlation does not exist in all deep basin cores. The reflector occurs above the Two Rivers till in seismic profiles, and it occurs below the Wilmette Bed identified in cores.

\section{Chippewa Unconformity}

A continuous, planar reflection ( $R 2)$ represents an unconformity that truncates the lower Lake Michigan Formation (figs. 11 and 17) on basin slopes and older units in the nearshore zone. The reflection (R2) can be traced to the deep basins where the unconformity grades into an equivalent conformable horizon that is also represented by reflection R2 (fig. 18). A west-to-east geologic section constructed from the seismic profiles illustrates this relationship (plate 2). In cores, a sand and shell layer separates underlying red glaciolacustrine mud and overlying gray postglacial lacustrine mud where the lower Lake Michigan Formation is truncated by reflection R2 on basin slopes (Hough, 1955; Wickham and others, 1978; Colman and Foster, 1990). Reflection R2 represents the equivalent conformity in the deep basins where cores show a gradational color change between underlying red glaciolacustrine clay and overlying gray postglacial clay, rather than a distinct lithologic contact (Wickham and others, 1978; Colman and Foster). We interpret the reflection R2 as the Chippewa unconformity and equivalent conformity of Hough (1955).

\section{Postglacial Sequence}

The postglacial seismic sequence (Qlu) is bounded at the top by the lake floor and at the base by reflection R2, which represents the Chippewa unconformity and equivalent deep basin conformity. In the deep basins, the sequence forms a conformable sheet that is acoustically transparent or contains weak, parallel, and continuous reflections. The postglacial sequence thins on basin slopes, except where thick lobes occur along the eastern slope of the lake (fig. 19). In cross-section, the lobes contain parallel, weak to moderate strength, continuous reflections that converge both towards the nearshore zone and the deep basins (fig. 


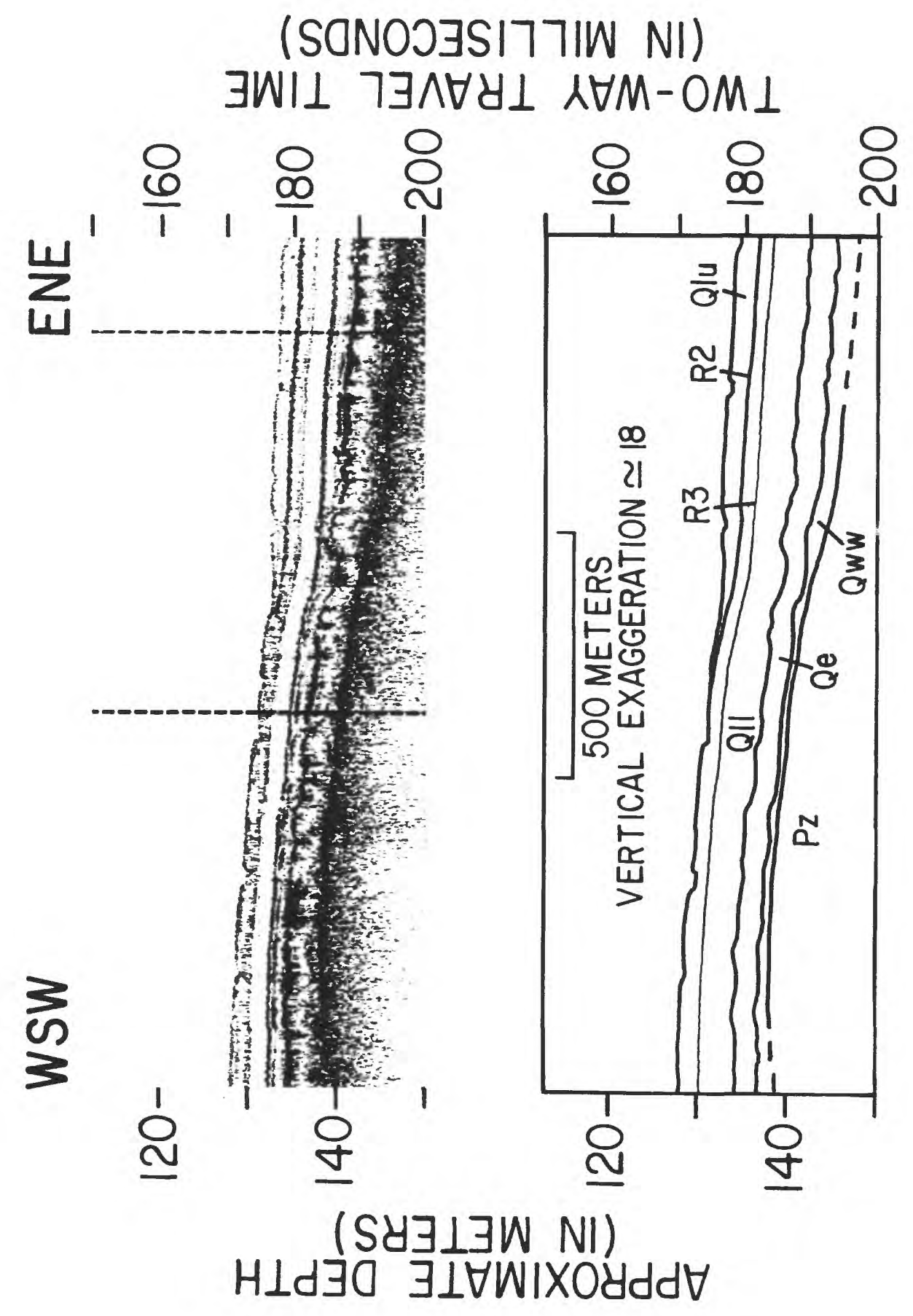

월

이을

寻

일.

记导

แ

要

T

돈

क 을

○ัษ

这官

을

, 등

플

동ㄴㅇ

대 -

동은

$\forall$ on

>를

렁

菅

号

녕

으을 을

톨

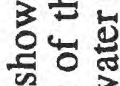

승.

농융

ज冓

लำ

(1) थ

퓽응

느를 노

등 융응

원

늠

눈 을

ن봉 용

盟

- 0

ऽ ड़ ह

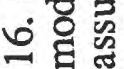

点 


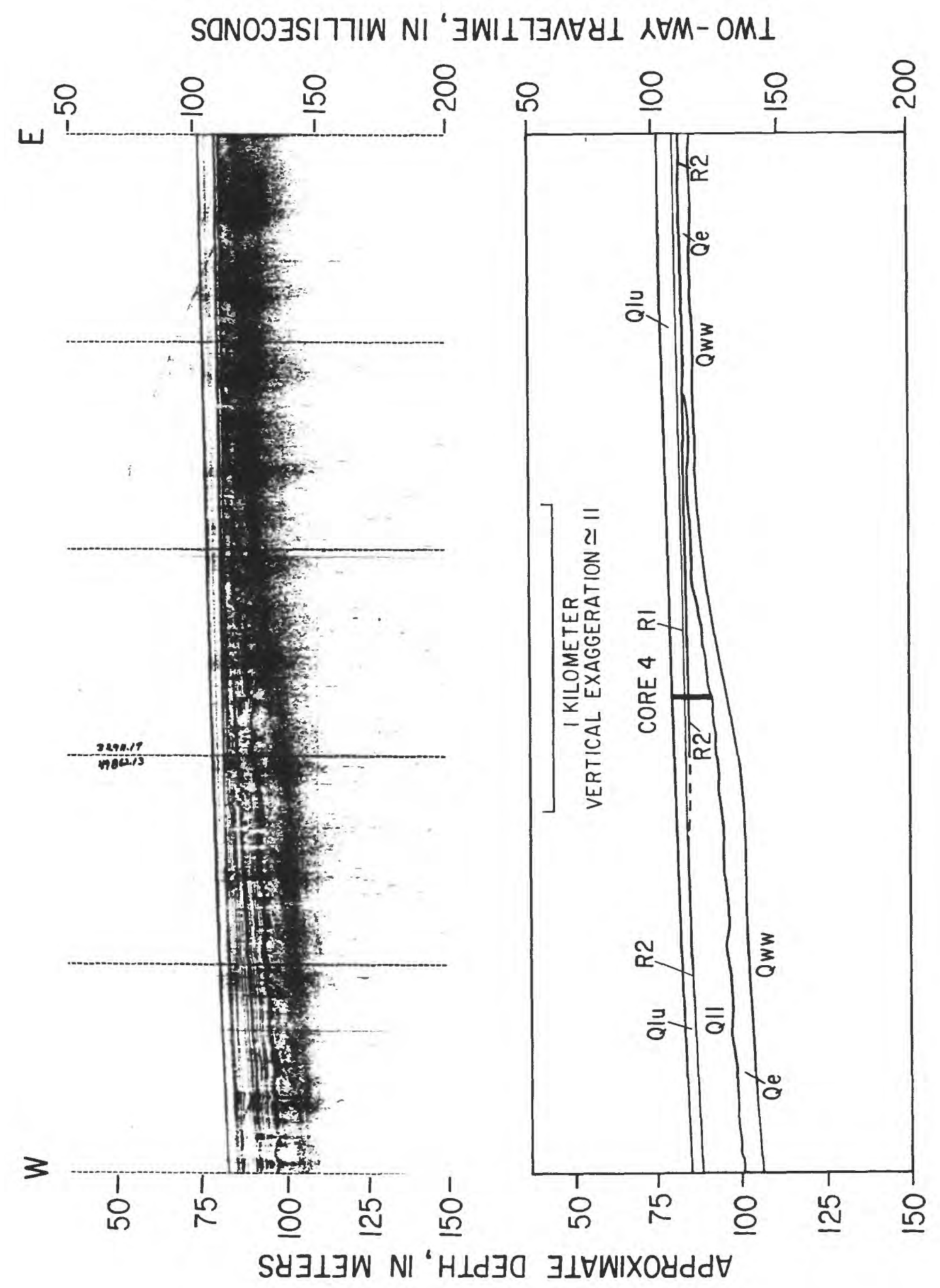

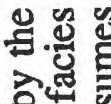

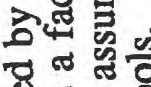

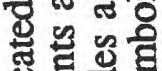

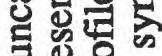
변염 온.는

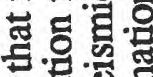
合坖 ธำ 링률 证 동 은 .ํํㄹำ 究。 o 일륭 ज䜤

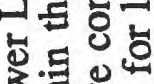
完告 零品

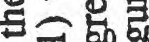
뜰 吅 동 ठํㄹㄹ \& on . $<0$ ํํํ롤 졸ำ 焉焉 ก 둥. ஸे 율

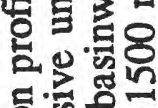
움 究的 绐

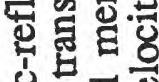

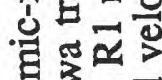
急定熍 量 


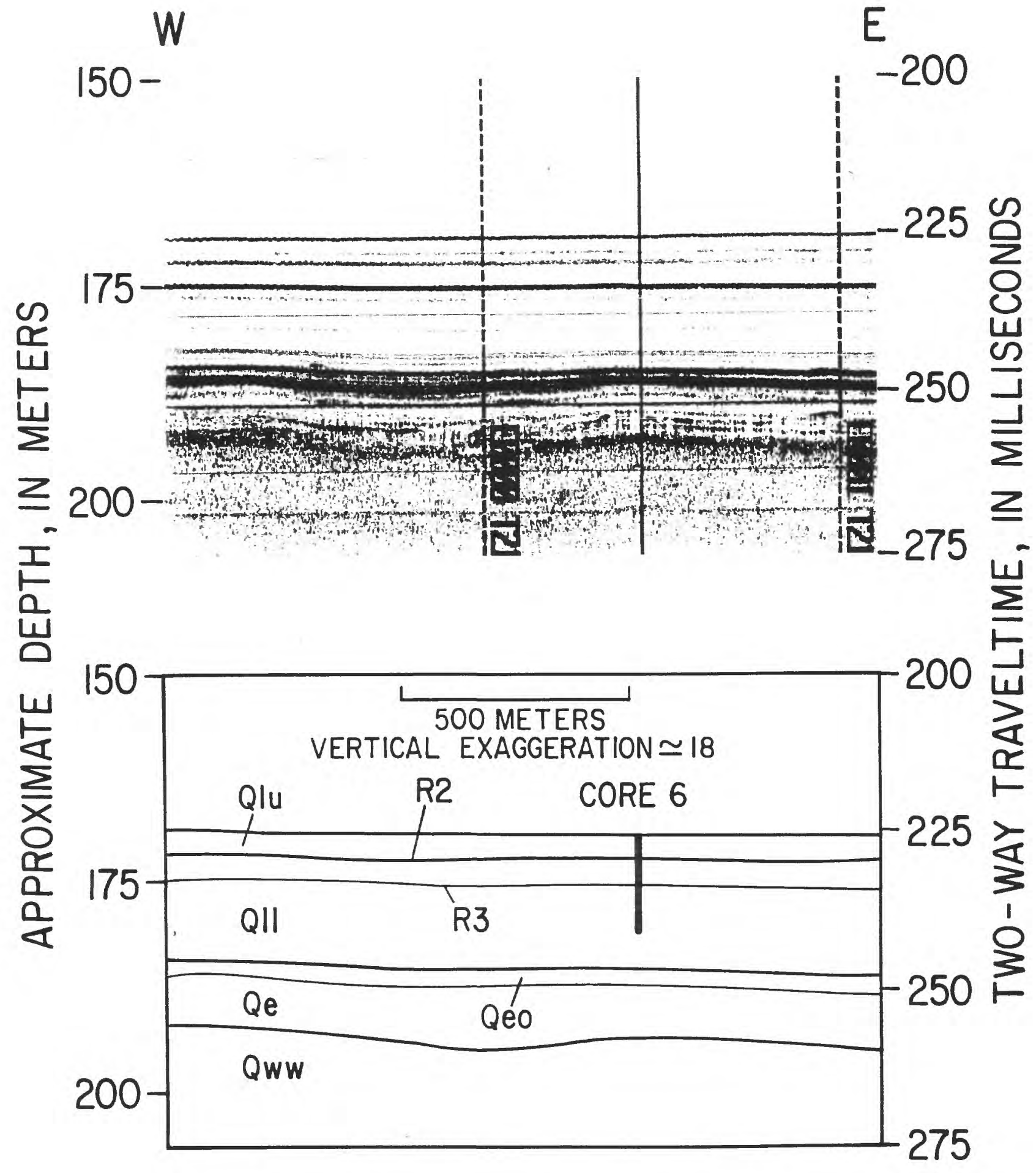

Figure 18. Seismic-reflection profile $(3.5 \mathrm{kHz})$ from the center of the southern basin. A weak reflection (R2) represents the equivalent conformity of the Chippewa unconformity. A strong reflection (R3) occurs within the lower Lake Michigan Formation (Q11). Depth scale on the seismic profiles assumes a sound velocity of $1500 \mathrm{~m} / \mathrm{s}$ in water and sediment. See figure 1 for location and figure 5 for explanation of symbols. 


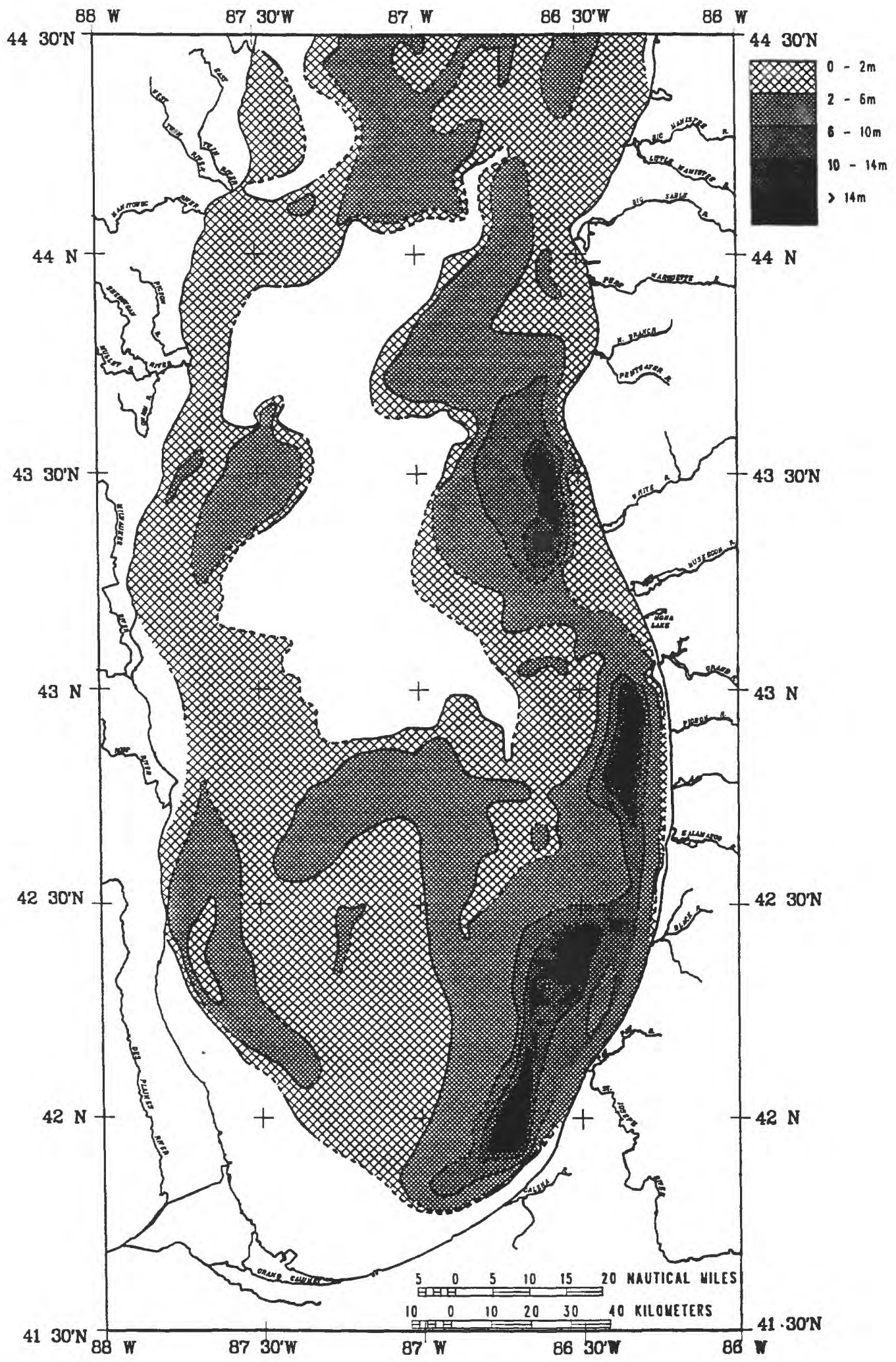

Figure 19. Map showing the thickness and distribution of postglacial lacustrine deposits; isopachs are dashed where inferred; thicknesses are unknown where isopachs do not exist (after Foster and Colman, in press). 
20). Acoustic penetration in the $3.5-\mathrm{kHz}$ profiles was locally hindered by biogenic gas trapped in the thickest part of the lobes; however, the broader frequency band and higher power of the seismic signal of the boomer-type systems was able to penetrate the postglacial sequence where gas occurs (fig. 20). Generally, the postglacial sequence pinches out in the nearshore zone or grades into a nearshore wedge of sand (fig. 21). Cores show that the postglacial sequence consists of gray to brown lacustrine silty clay in the deep basins, which grades into sand deposits in the nearshore zone (Wickham and others, 1978; Colman and Foster, 1990). We informally call the postglacial sequence the upper Lake Michigan Formation (Qlu). It corresponds to the Waukegan, Lake Forest, and Winnetka Members (fig. 3b) of Lineback and others (1970).

Between 42 and $94 \mathrm{~m}$ below present lake level, a strong, planar, continuous reflection (R1) occurs locally within the postglacial sequence (Qlu), usually within a meter above the reflection (R2) that represents the Chippewa unconformity (fig. 4). On the western slope of the southern basin, the upper reflection (R1) converges basinward with the lower reflection (R2). In other areas, particularly on the eastern slope of the southern basin, the lower reflection (R2) fades out basinward, and reflection R1 is inferred to converge with reflection R2 (fig. 17). The upper reflection (R1) also converges with the lower reflection $(\mathrm{R} 2)$ towards the nearshore zone.

The asymmetric distribution of postglacial deposits is extreme (fig. 19). Thick deposits (almost $20 \mathrm{~m}$ ) occur on the eastern slopes of the lake basin. In contrast, $2-4 \mathrm{~m}$ of postglacial sediment occur in most deep basins, and large areas of the lake floor are virtually free of postglacial deposits.

On the eastern slope of the lake basin, postglacial deposits form three distinct lobes (fig. 19) that in cross-section form wedges that thin both shoreward and basinward (fig. 20). Postglacial sediment wedges occur as slope-front fill deposits, i.e., the thickest part of the wedges fill the concave-upward inflection in slope at the base of the postglacial deposit, the Chippewa unconformity. The thickest part of the lobes are located south of the St. Joseph River, south of the Grand River, and north of the Muskegon and White Rivers (figs. 2 and 19).

In the deep basins, postglacial deposits are generally uniform in thickness. In the southern basin, postglacial deposits are mostly 2-3 m thick in a band that curves around the eastern and northern side of the southern basin (fig. 19). Elsewhere in the southern basin, postglacial deposits are generally less than $2 \mathrm{~m}$ thick. The deeper parts of the northern basin generally have 2-4 m of postglacial deposits in depressions that lie between bathymetric highs, whereas less than $2 \mathrm{~m}$ of postglacial sediment has been deposited over bathymetric highs. The western mid-lake basin has an evenly distributed thickness of slightly more than $2 \mathrm{~m}$ of postglacial sediment. The eastern mid-lake basin contains 2-4 m of postglacial sediment except along the northeastern basin margin where part of a lobe of postglacial sediment, as much as $14 \mathrm{~m}$ thick, extends from the eastern basin slope into the basin (fig. 19). The northern mid-lake basin has a relatively even thickness of postglacial deposits, which are 4-6 m thick in the center of the basin.

Two large regions of the lake floor have virtually no postglacial deposits (fig. 19). The first is a broad shelf off the Illinois and western Indiana shore; this area is locally veneered with thin patches of postglacial sediment, some of which are probably lag deposits (Hough, 1935). Sand and gravel deposits as much as a few meters thick underlie nearshore ridges, particularly between Indiana Shoals and off Chicago (fig. 22). The second major area that contains little or no postglacial sediment is the mid-lake high and the northern ridge. The sill between the eastern mid-lake basin and the southern basin as well as the sill between the western and northern mid-lake basins also appears to have little or no postglacial deposits. 


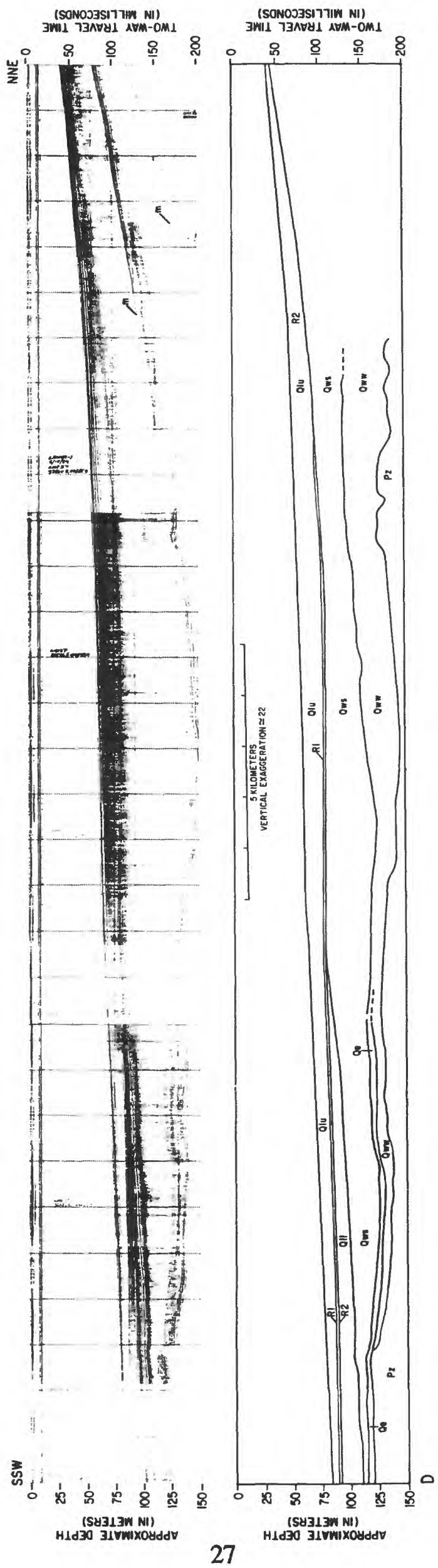

娄题

氙歁

으. 낭

옹.

$\dot{0}$

음

. ํํㄹ원

은

है들

ด區

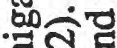

ड्र

$\sum$

产园

屯형

을임

일

虫

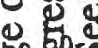

(5)

है

4 क

궁

$\rightarrow$ है

일 है

\%

है

(2).5

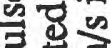

尼

递实

트

․ㅗㄱㄴㄷㅇ

음를

응

들

क्ष

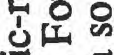

로

跑

तं

号

疍 

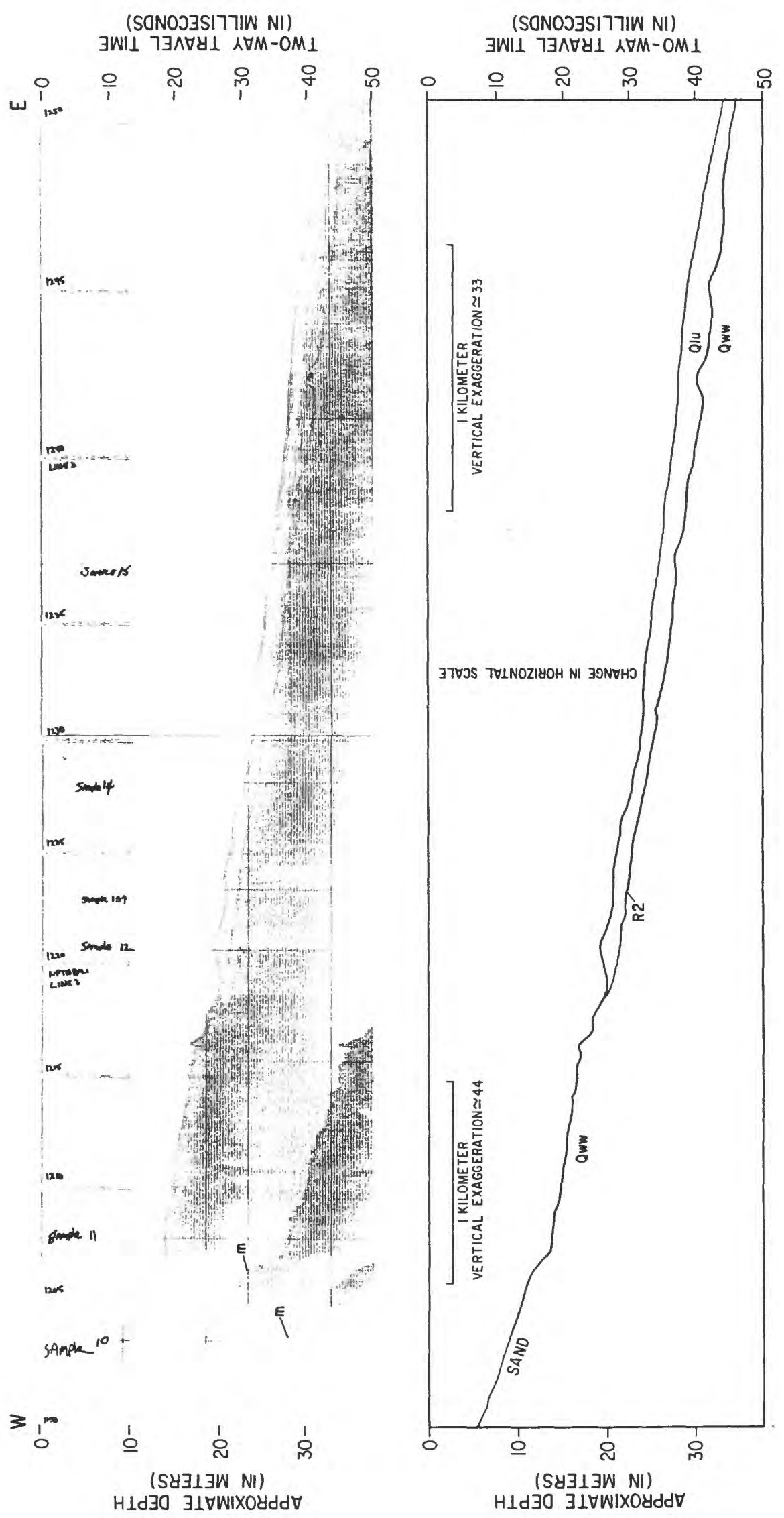

它岁总帝

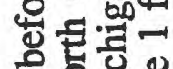

을 을

崖整

莺票

要

동현

o

늘

6o

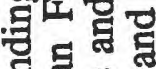

品品

․ㅡㅇ

군 3

금ㅍ

o ธ뎔

년?

틀

옴ㅇㅇ

동

.0

은은?

为氙

용

ज讨

प

응 ส

들 정

s 8

00 은

\%的 6

ㄷ.ㄴㄹㄹ

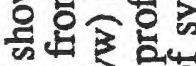

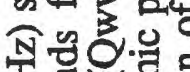

可进

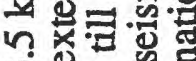

ci 5

总

닐

영

혈률

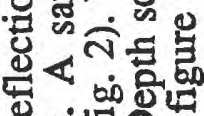

苛式口

음

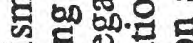

矛乐

के है

तं.

을 


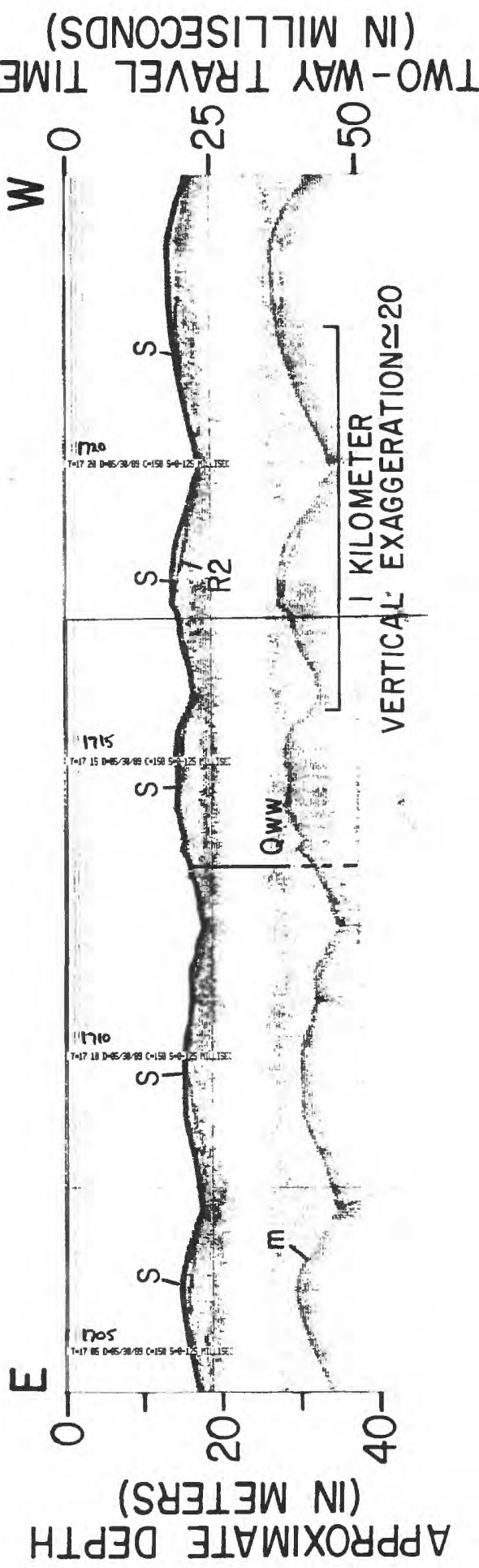

总总

돌로

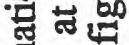

․ㅡㄹ

ชิธ

eै

品已

를

흉혀

宁莫

4

2.

앰르

넝 댑요

뜬

家范

응을

五

政

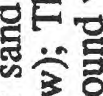

4t

임

ㄷ⿺월

零

을르융

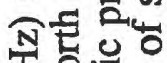

妾을

늘.

c.

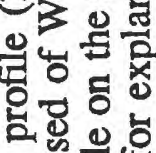

ธ.

긍

造

\%

일율룰

. 00 要 ․․․ 0.

त่

总 


\section{OTHER FEATURES OBSERVED ON SEISMIC PROFILES}

Several features that may be related low lake levels can be seen in the seismic profiles. These features include possible wave-cut benches and scarps, beach deposits, and ridges. However, corroborating evidence for a shoreline origin of these features is lacking, and we have generally been unable to trace individual features between seismic profiles. Submerged paleochannels and a paleodelta indicate low lake levels, but the age and association of these features with a paleoshoreline is uncertain.

Benches and scarps are cut into till deposits at depths of $24 \mathrm{~m}$ (fig. 23) to $125 \mathrm{~m}$ below present lake level (fig. 24) and vary in height from a few meters to as much as $35 \mathrm{~m}$ (fig. 24). These benches may be submerged wave-cut bluffs. The minimum ages of these features is uncertain except where lacustrine sediments onlap the scarps. The scarp-toe at $125 \mathrm{~m}$ depth (fig. 24) is onlapped by the lower Lake Michigan Formation (Qll); therefore, if this scarp were cut during a glacial lake stage, it predates the Chippewa low lake level. A scarp-toe at $32 \mathrm{~m}$ depth is onlapped by a wedge of the upper Lake Michigan Formation (Qlu) (fig. 25). This scarp may have been cut during the pre-Nipissing transgression that followed the Chippewa low level. Till scarps may have formed by glacial processes thus may not relate to paleo-lake-level.

Submerged-beach or relict-nearshore-sand deposits appear as wedges on the seismic profiles (fig. 26). These deposits are preserved where a sharp break in slope occurs in bedrock (fig. 26) or till (fig. 25). The deepest occurrence of one wedge reaches a water depth of $78 \mathrm{~m}$ (fig. 26). These wedges may have been deposited in a beach or nearshore environment during a stillstand in the transgression from the low Chippewa level.

Asymmetric ridges that have relief of 2-8 $\mathrm{m}$ and spacing of about 100-200 $m$ (fig. 27) were observed in a few locations. Their lateral extent are not known. The ridges are preserved along shelf edges where there is a distinct break in slope. Reflector (R2), which represents the Chippewa unconformity, is continuous beneath the ridges. The ridges are probably sand waves that formed during or after the transgression that followed the Chippewa low level. Most of the ridges are apparently relict forms as they occur at depths of 18 to $80 \mathrm{~m}$ below present lake level.

Offshore of the Grand River, prograding reflections represent foreset beds of a paleodelta that is preserved beneath the upper Lake Michigan Formation and a remnant of the lower Lake Michigan Formation (fig. 28). From its stratigraphic position, the delta represents a glacial low lake level, after the Glenwood II high level, which was associated with the glacial readvance that deposited Shorewood till. The delta may have been deposited during the Two Creeks or Main Algonquin low stages. The preserved delta foresets range from 42 to $78 \mathrm{~m}$ below present lake level. The tops of paleochannels that occur landward of the paleodelta (fig. 28) are about $30 \mathrm{~m}$ below present lake level. If the paleochannels were distributary channels that formed at the same time as the paleodelta, the depth of $30 \mathrm{~m}$ below present lake level may represent a stillstand level. This depth of $30 \mathrm{~m}$ is much less than the $116 \mathrm{~m}$ below present Lake level suggested for the Main Algonquin level in the southern basin by Larsen (1987).

Only one other paleochannel occurs on the seismic profiles in the southwest corner of the lake (fig. 23) at a depth of about $20 \mathrm{~m}$ below present lake level. Its minimum age is not known.

Paleoshoreline features, paleochannels, and deltas are generally not well preserved below present lake level in the southern two-thirds of Lake Michigan. Isolated occurrences of such features are at a variety of depths and are difficult to trace between seismic profiles. The transgression that followed the low Chippewa level apparently eroded most paleochannels and paleoshoreline features. 


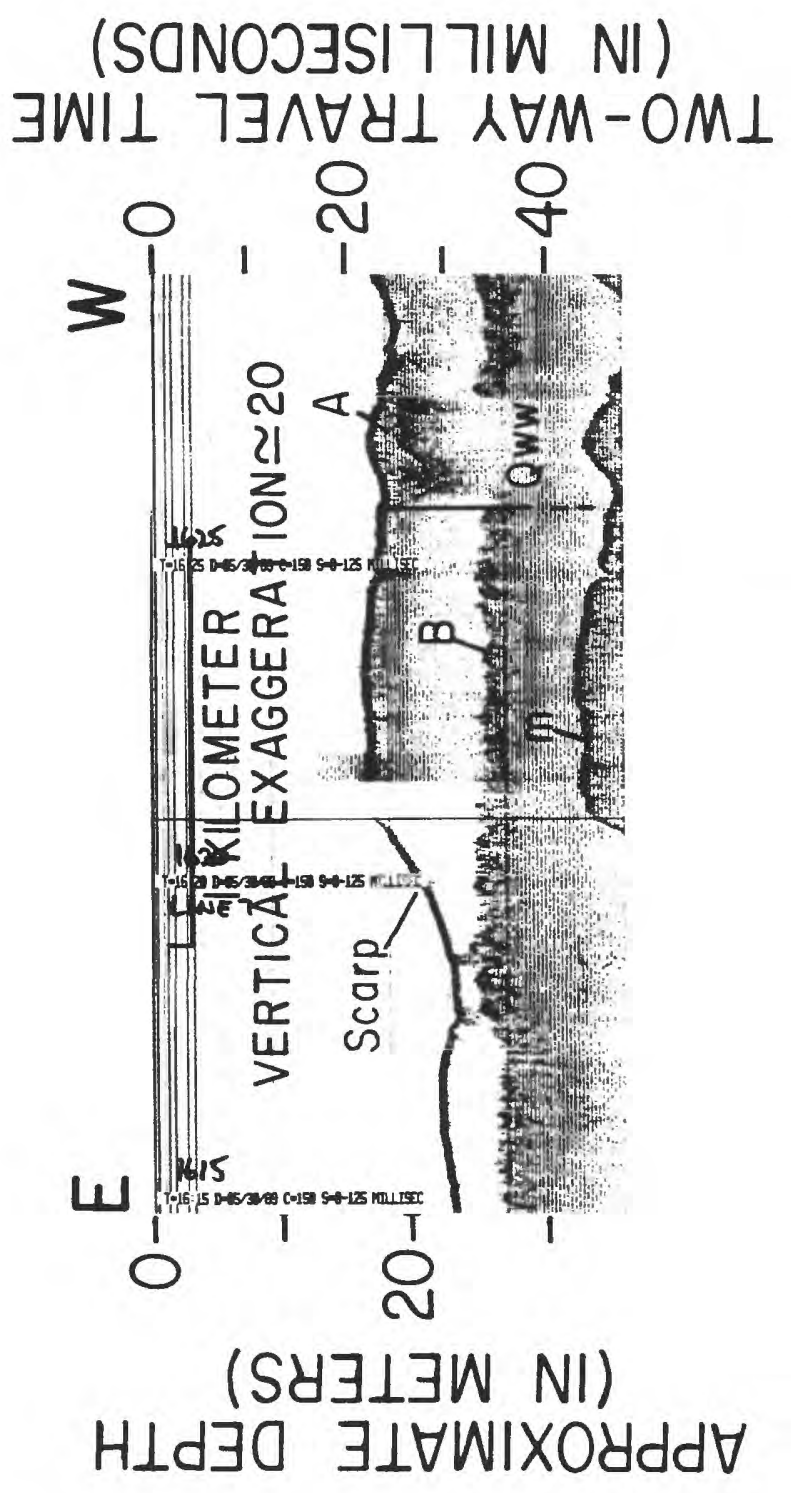

ㅎํ욤

용

$=0$

큥ำ

든

엄리

웜

ऐ르 कै

틀들

낭

르은

๙

읃

寻齿

들

수융 ญ

는.

ติ

บ $\mathrm{m}$ 궁

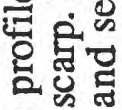

응 올 峁

บ눙

뉸잉. 드

ஸे क

붕

造

๗ั.

逍 


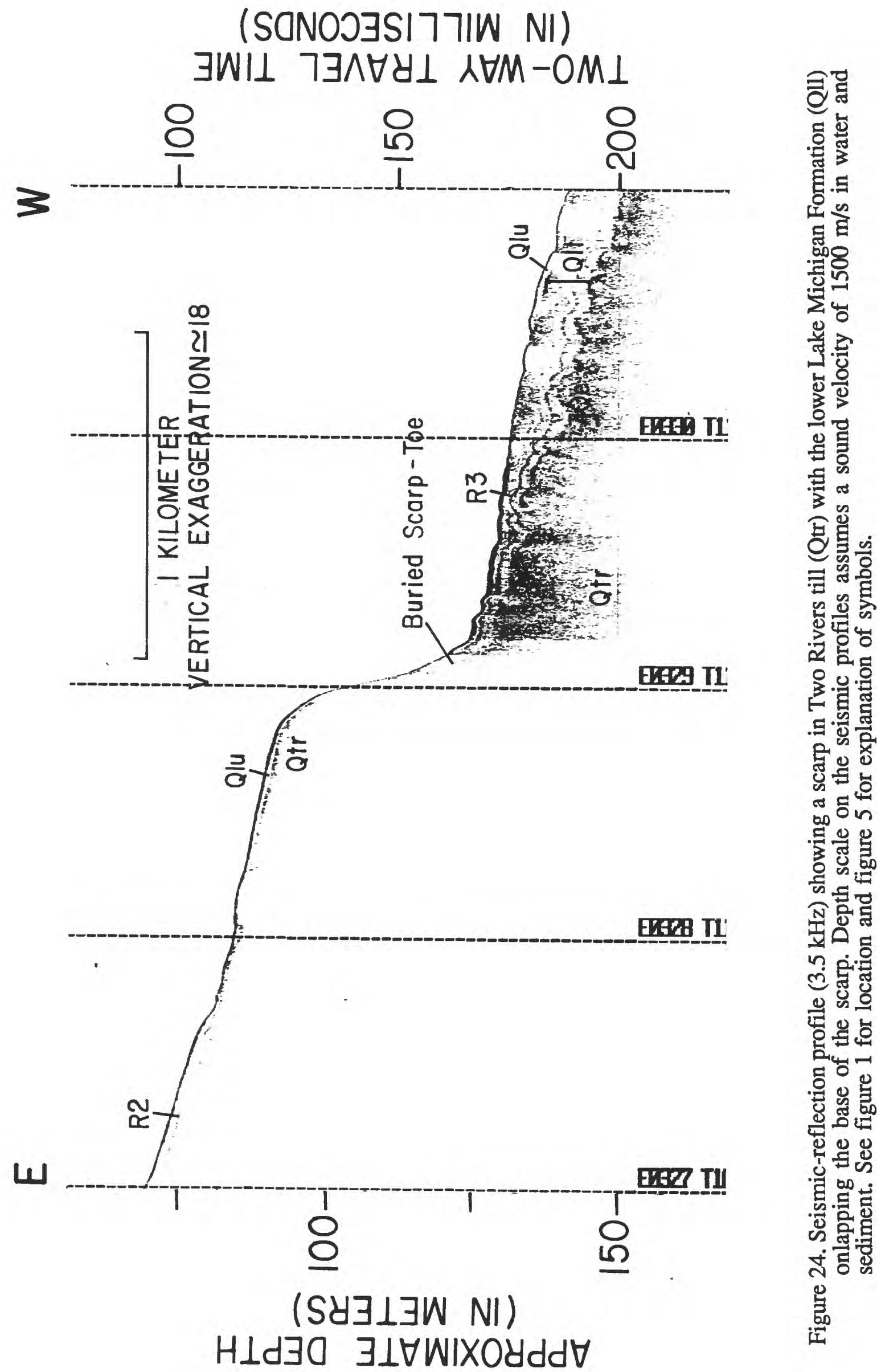




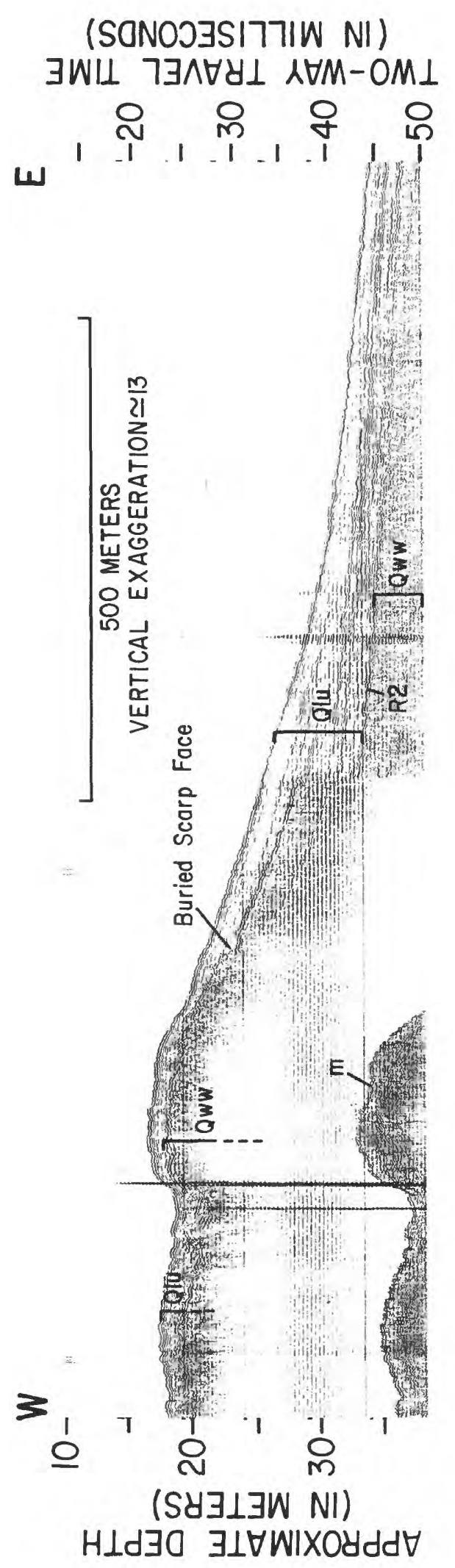

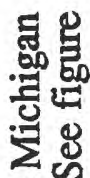

藏

妾:

용

올

㟧

品

․․․

क व

웡

ชู

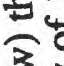

它

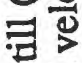

륭를

중

ए

.

นิ

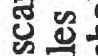

훙

os

.0

क

तิ

吉运

กำ

은

论

员昰

드융

호를

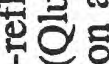

믐듀웛

늘

थ 댄

กิ่

营 

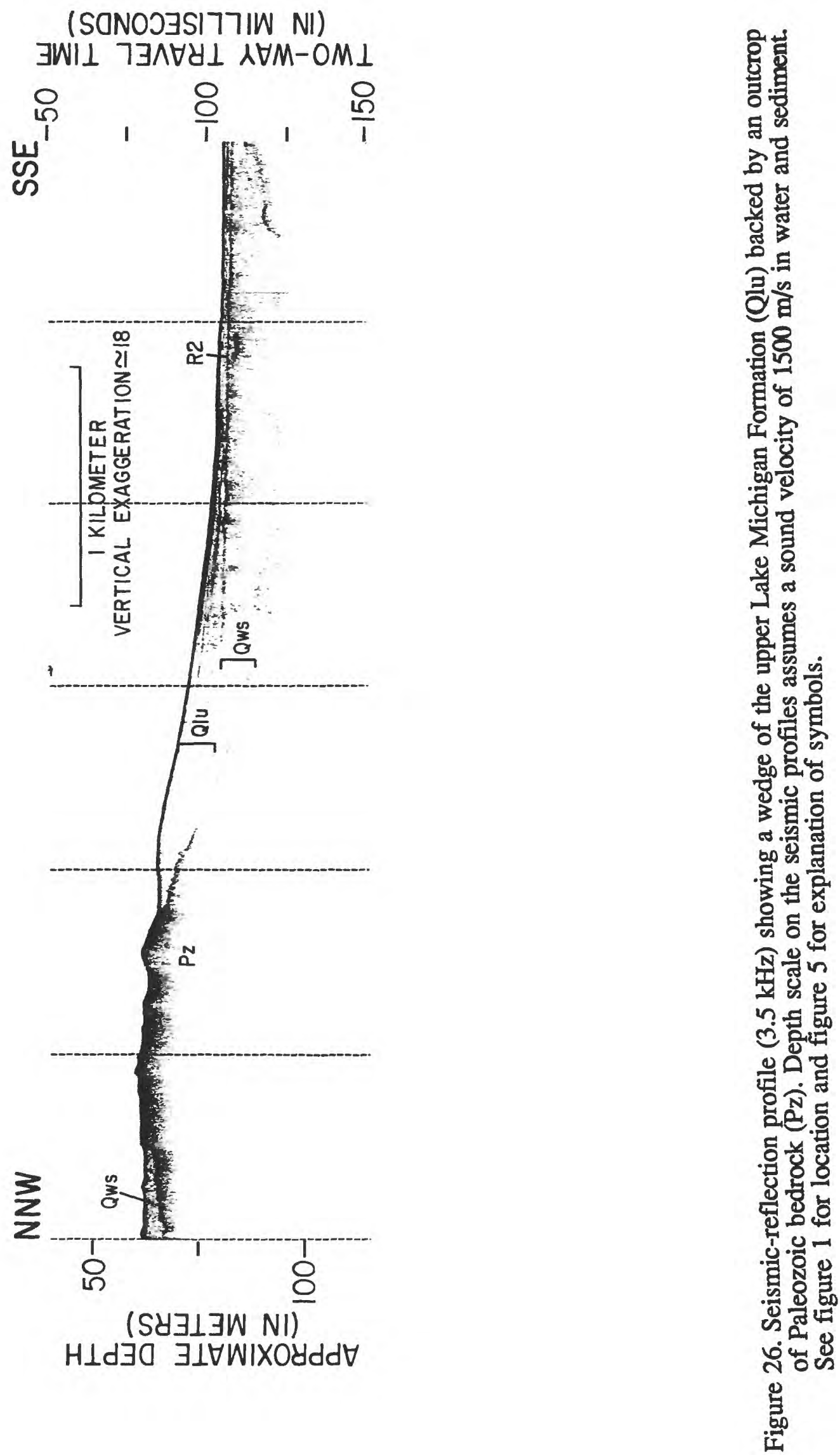


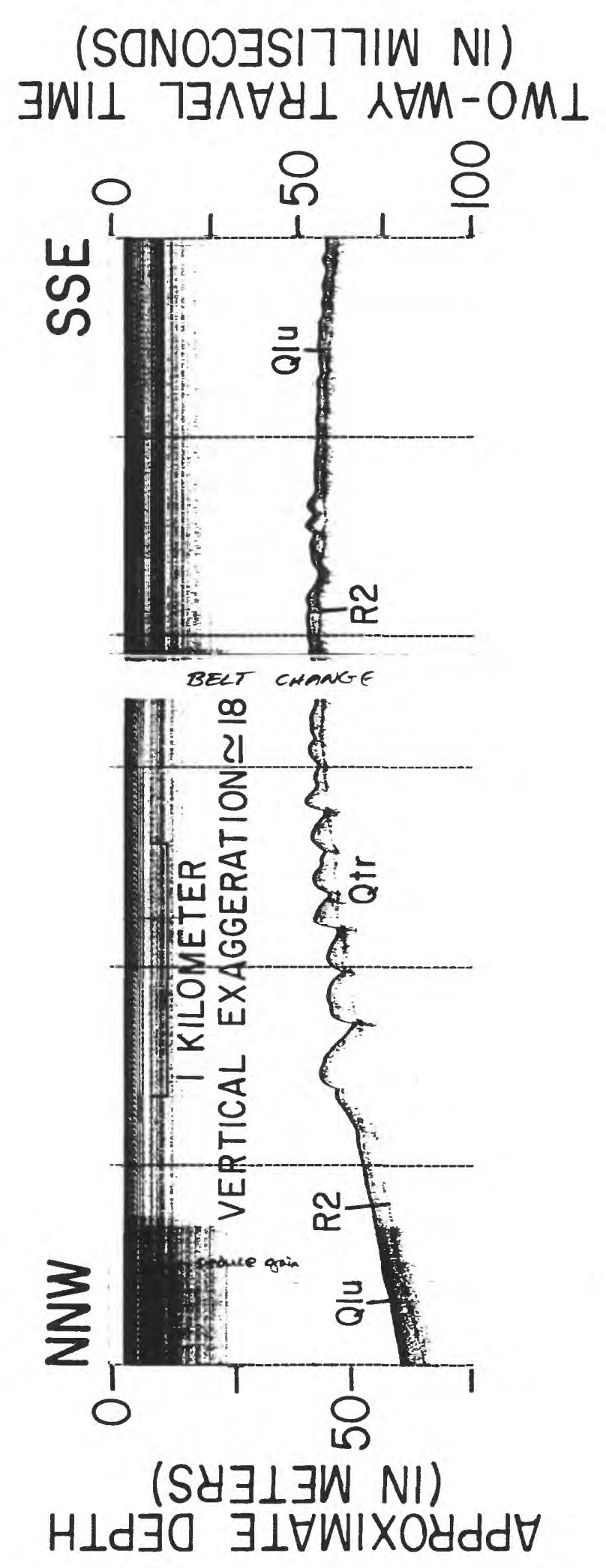

椐

웅

ธิ

․․

श है

芴

o

品

등

类.

을

踶

๖

드

3

\&

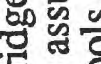

的类

旨总茝

흔응

ह.

สํํㄹ

헝

\%

和

कี

ong n

I

论

올

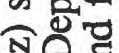

주의

\%

n.

듬

응

형

.옹 잉

8

원

ن

․ㅗㅇ

ผ

穴造

总 

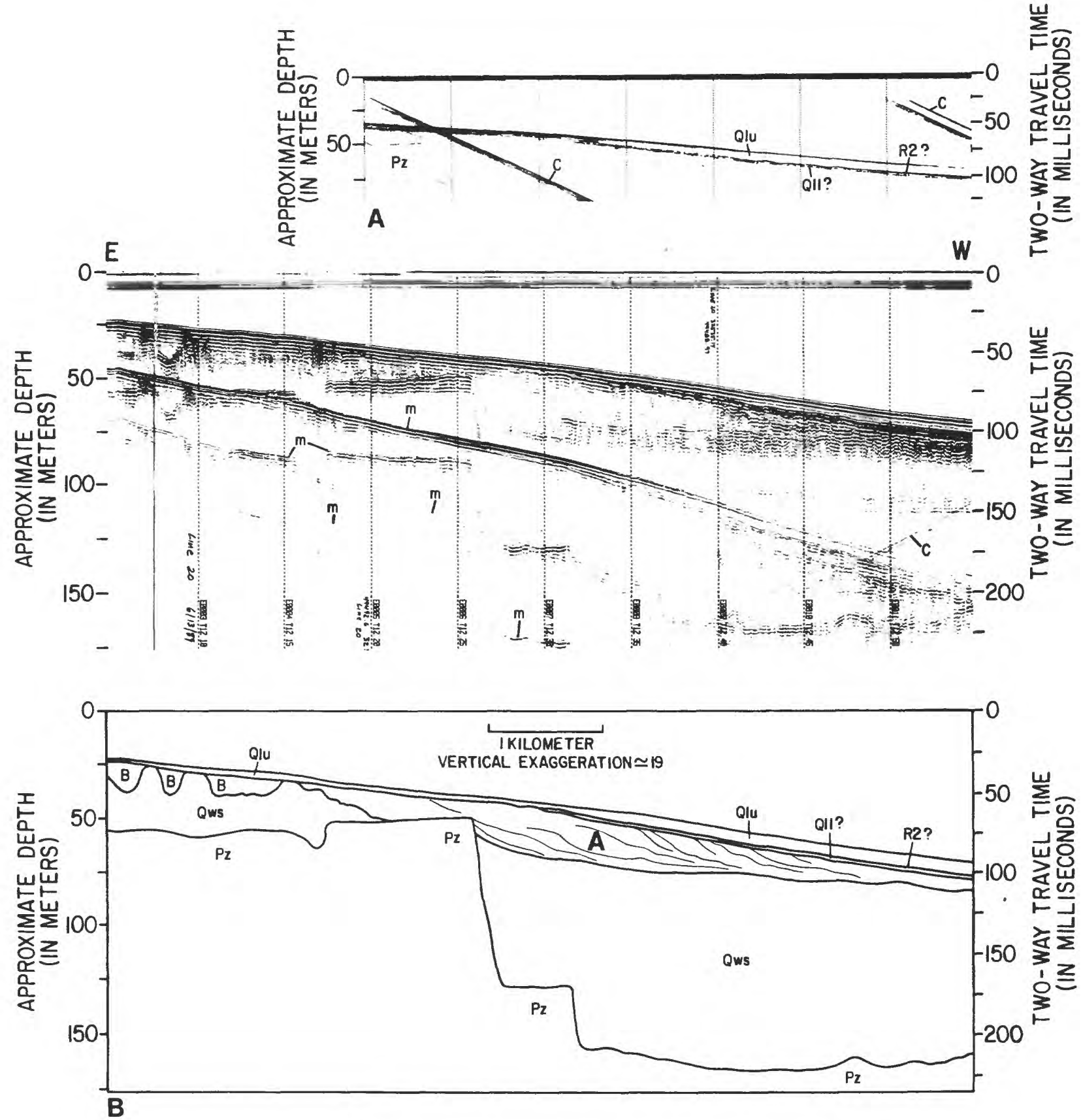

Figure 28. Seismic-reflection profiles (profile A, $3.5 \mathrm{kHz}$ and profile B, Geopulse). Profile B shows prograding internal reflections within a paleodelta sequence (A) and cut-and-fill channels (B) shoreward of the paleodelta. Profile A shows a remnant of the lower Lake Michigan Formation (Q11) beneath the upper Lake Michigan Formation (Qlu) and Shorewood till (Qws). Depth scale on the seismic profiles assumes a sound velocity of $1500 \mathrm{~m} / \mathrm{s}$ in water and sediment. See figure 1 for location and figure 5 for explanation of symbols. 


\section{GEOLOGIC HISTORY}

The late Wisconsinan and Holocene geologic history of the southern twothirds of Lake Michigan can be reconstructed from the seismic stratigraphy, verified by lithostratigraphy from cores. The seismic stratigraphy clearly defines two major depositional units: (1) glacial deposits, and (2) postglacial deposits. Till, ice-proximal and ice-distal sublacustrine outwash, and glaciolacustrine facies were deposited during deglaciation. Evidence of lake level fluctuations during glacial deposition is not well preserved in the stratigraphy beneath Lake Michigan. The only clear evidence of low lake levels is the Chippewa unconformity, which truncates glacial deposits. The Chippewa unconformity marks a shift in sediment source and depositional processes in the Lake Michigan basin. Glaciolacustrine deposition was focused in the deep basins, whereas postglacial depositional processes have resulted in an asymmetric distribution of Holocene deposits.

The Lake Michigan ice lobe readvanced four times during overall retreat through the Lake Michigan basin. Three till units, the Shorewood (Qws), Manitowoc (Qwm), and Two Rivers (Qtr) tills of Lineback and others (1974), and another previously unidentified till (Qwu) terminate at till margins beneath the lake (plate 1). The till margins (fig. 10) indicate the position of the maximum readvancement of the Lake Michigan ice lobe. High lake levels, the Glenwood and Calumet levels, coincided with these glacial advances, and low lake levels, the intra-Glenwood and Two Creeks levels, occurred with glacial retreat (Hansel and others, 1985).

With each retreat of the glacier in the lake basin, ice-distal sublacustrine outwash of the Equality Formation (Qe) was deposited over till. Sublacustrine outwash in the deep basins grades laterally into till on the basin slopes, an indication that the preserved Equality Formation was deposited at the same time or soon after the till. Glacial advances deposited till over the Equality Formation, which resulted in intercalated till and sublacustrine outwash deposits. Ice-proximal sublacustrine outwash grades into till at till margins, and therefore were deposited simultaneously with till. These deposits fan out from the till margins, most noticeably along the Shorewood till margin in the southern basin (figs. 10 and 12).

We infer that the lower part of the glaciolacustrine lower Lake Michigan Formation was deposited in association with the Equality Formation and the reddish-brown Shorewood, Manitowoc, and Two Rivers tills; the red color of these deposits originate from iron-rich bedrock in the Lake Superior basin (Dell, 1975; Lineback and others, 1979). In contrast, Wickham and others (1978) suggested that deposition of the lower Lake Michigan Formation did not begin until the retreat of the Two Rivers glacier. They suggested that the lower Lake Michigan Formation is acoustically transparent in the southern basin with internal reflectors more common in the northern basin. They interpreted from this difference in seismicfacies that deposition was relatively uniform in the southern basin, and that variable, coarser-grained deposition occurred in the northern basin, close to the retreating Two Rivers glacier. We observe acoustically transparent facies as well as facies containing continuous reflections in the lower Lake Michigan Formation in both the southern basin (fig. 16) and the northern basin. From this, we infer that the distance from the sediment source to the southern basin was variable during the deposition of the lower Lake Michigan Formation. Also, lateral seismic-facies transitions (fig. 13) between the lower Lake Michigan Formation, the Equality Formation, and the Shorewood and younger till units indicate co-deposition of these facies in contiguous environments. The presence of ice-rafted dropstones in cores that penetrate the lower Lake Michigan Formation (Colman and Foster, 1990) further suggest that at least the lower part of the lower Lake Michigan Formation was deposited while ice was present in the Lake Michigan basin, beginning with the deposition of Shorewood till.

Deposition of the glaciolacustrine lower Lake Michigan Formation continued with the retreat of the glacier from the Two Rivers till margin (about 11 $\mathrm{ka}$; Hansel and others, 1985). A marker reflection (R3) within the lower Lake 
Michigan Formation overlies Two Rivers till. Therefore, the lower Lake Michigan Formation above reflection R3 and part of the lower Lake Michigan Formation below reflection R3 was deposited after the Two Rivers began to retreat.

Reflection R3, within the lower Lake Michigan Formation, may be associated with a significant low glacial lake level. Unconformities that formed during glacial lowstands less than $70 \mathrm{~m}$ below present lake level have not been preserved, because the Chippewa unconformity (R2) has truncated the lower Lake Michigan Formation to depths of 70 to $100 \mathrm{~m}$ below present lake level. Although unconformities related to low glacial lakes have been eroded, their equivalent conformable horizons are likely to be preserved within the lower lake Michigan Formation in the deep basins, in the same way reflection R2 represents a conformable horizon in the deep basins. We infer that reflection R3 represents such a conformable horizon, and that reflection R3 relates to a low lake level that occurred sometime after the Two Rivers glacial advance and the correlative high Calumet level (11.8 to $11.2 \mathrm{ka}$; Hansel and others, 1985), but before deposition of the Wilmette Bed (11 to $10 \mathrm{ka}$; Drexler and others, 1983), which overlies reflection R3. This timing suggests the association of reflection R3 with the beginning of the Main Algonquin stage of Lake Michigan, inferred by Larsen (1987) to be a low level lake that occurred when the Mackinac Straits were deglaciated at about 11.2 $\mathrm{ka}$, and lake level was controlled by the Mink Lake Sill in Ontario (Larsen, 1987).

The Wilmette Bed, a distinctive gray marker bed observed in cores (Colman and Foster, 1990), occurs within the lower Lake Michigan Formation above reflection R3. We did not observe a reflection correlative with the Wilmette Bed on our seismic profiles, in contrast to the inference of Lineback and others (1971). The Wilmette Bed may have been deposited when glacial meltwater from the Superior basin, the source of red clay, was cut off from the Lake Michigan basin during deglaciation of the Superior basin, between 11 and $10 \mathrm{ka}$ (Drexler and others, 1983; Hansel and others, 1985; Colman and Foster, 1990).

The red clay deposited above the Wilmette Bed may have come from meltwater that flowed across the Upper Peninsula of Michigan into the Lake Michigan basin during the advance and retreat of the Marquette glacier in the Superior basin (10 to $9.8 \mathrm{ka}$; Drexler and others, 1983; Teller, 1985). Alternatively, Wickham and others (1978) and Lineback and others (1979) suggested that reworked red clay was deposited over the Wilmette Bed during the regression of the lake to the low Chippewa level. In addition to reworked red clay deposited during the low Chippewa Stage, reworking of red clay may have also occurred during the low Main Algonquin Stage of Lake Michigan.

Larsen (1987) suggested that the elevations of the top of the red clay of the lower Lake Michigan Formation, which generally rise to the north, were broadly contemporaneous with the Main Algonquin level (11.2 to $10.5 \mathrm{ka}$ ) in Lake Michigan. However, the Chippewa unconformity truncates the red clay on basin slopes, suggesting the red clay was formally more extensive. The maximum elevation of the Sheboygan Member, $82 \mathrm{~m}$ below present lake level (Lineback and others, 1972), was once higher. Our seismic profiles indicate that red clay of the lower Lake Michigan Formation has been truncated between 70 and $98 \mathrm{~m}$ below present lake level in the southern basin, and the level of truncation descends to the north. We suggest that the upper limit of red clay in the southern basin was $70 \mathrm{~m}$ or less below present lake level, and the present elevation of the red clay is where red clay is truncated by the Chippewa unconformity. The present elevation of the red clay is apparently lower than the minimum elevation of a the Main Algonquin of Lake Michigan of Larsen (1987).

The planar, smooth reflection and absence of erosional channeling where reflector R2 truncates the lower Lake Michigan Formation suggests that the associated unconformity was formed subaqueously by wave erosion. We infer that the unconformity formed during the transgression from the low Chippewa level $(10.3 \mathrm{ka})$ to the Nipissing level ( $5 \mathrm{ka}$ ), which was about $8 \mathrm{~m}$ above present lake level (Hansel and others, 1985; Larsen, 1985a,b).

In the absence of strandline features, the minimum Chippewa low level can 
only be determined from the maximum depth of the Chippewa unconformity, from which the depth of wave-base erosion must be subtracted. Our seismic profiles show the truncation of the lower Lake Michigan Formation occurs to depths of more than $70 \mathrm{~m}$ below present lake level. The Chippewa unconformity extends deeper than the truncation of the lower Lake Michigan Formation and grades into a conformable horizon. Because of this gradation, the exact depth of the limit of the unconformity can not be determined from the seismic profiles.

The maximum depth of the sand and shell zone at $107 \mathrm{~m}$ below present lake level, determined from cores (Hough, 1955), is probably close to the maximum depth of the Chippewa unconformity. However, Hough (1955) did not account for wave-base erosion, which has been estimated for modern Lake Michigan to be as much as $46 \mathrm{~m}$ (Sly and Thomas, 1973) or possibly deeper (Hands, 1983). Wave base may have been less during the low Chippewa level, because the fetch was limited by the smaller size of the nearly isolated southern basin. Wickham and others (1978) placed the maximum depth of the unconformity at $82 \mathrm{~m}$ below present lake level, the level at which the red clay of the lower Lake Michigan Formation pinches out by truncation on basin slopes. They assumed a 20 $\mathrm{m}$ wave base, and suggested that the Chippewa level reached a depth of $62 \mathrm{~m}$ below present lake level. We suggest that the maximum depth of the unconformity is greater than $82 \mathrm{~m}$ below present lake level, because seismic profiles show that the unconformity extends deeper than the pinch out of the red clay, as the sand and shell zone from cores suggest (Hough, 1955).

A sill separates the southern and eastern mid-lake basins and has a threshold of about $102 \mathrm{~m}$ below present lake level (fig. 2). Hough $(1955,1958)$ and Larsen (1987) suggested that during the minimum Chippewa low level a separate lake, Southern Lake Chippewa, in the southern basin spilled across the sill into main Lake Chippewa, on the assumption that the Chippewa lowstand was more than $100 \mathrm{~m}$ below present lake level. Hough (1958) referred to a channel that connected the basins across the sill as the Grand Haven River. Where our seismic lines cross parts of the sill (fig. 1), there is no indication of a fluvial channel on the seismic profiles. Therefore, we suggest that the Chippewa lowstand was not any lower than the depth of the sill (about $102 \mathrm{~m}$ ), and the southern basin was not separated from the eastern mid-lake basin during the Chippewa low level.

A lens-like deposit locally preserved between reflector $R 1$ and the Chippewa unconformity (R2) (fig. 4) is interpreted to be a transgressive lacustrine deposit. The upper reflection (R1) may occur at a facies change within the postglacial unit, where a change from relatively high energy to low energy deposition occurred as lake level transgressed from the Chippewa low level.

The distribution and thickness of postglacial deposits (fig. 19; Foster and Colman, in press) suggests variable rates of sedimentation that reflect postglacial processes during the past 10,000 years. We agree with Lineback and Gross (1972) that the thick postglacial deposits on the eastern slope (fig. 19) reflect sediment sources from rivers along the Michigan coast as well as sediment derived from coastal erosion and that lake circulation has affected the distribution of postglacial sediment. Sedimentation rates are higher on the eastern side of the southern basin, where thick postglacial deposits occur, compared to relatively low sedimentation rates and thin postglacial deposits on the western side. Modern sedimentation rates are also inferred to be higher on the eastern side of the southern basin, on the basis of concentrations of anthropogenic trace elements (Lineback and Gross, 1972) and organic compounds in the surface sediment (Eadie and Robbins, 1987). The pattern of concentration of these materials in the surface sediment is similar to the pattern of postglacial sediment thickness (Lineback and Gross, 1972; Foster and Colman, in press). The spatial association of high modern sedimentation rates with thick postglacial deposits suggests a relatively uniform pattern of deposition over the past 10,000 years. However, rates of deposition do not appear to have been constant, either on the western side of the southern basin (Colman and others, in press), or on the eastern side (Rea and others, 1980). Preliminary radiocarbon dates and faunal analyses (S.M. Colman, unpublished data) suggest that much of the sediment 
in the thick lobes on the eastern side of the lake basin was deposited very rapidly, shortly after $10 \mathrm{ka}$. If this conclusion is correct, it minimizes the large contrast in sedimentation rates suggested by the thickness data.

In the deep basins, our seismic profiles show a strong reflection (R3) that occurs within the lower Lake Michigan Formation; a weaker reflection (R2) (fig. 18) separates the upper from the lower Lake Michigan Formation. All of the available core data (Hough, 1955, 1958; Lineback and others, 1970, 1971, ,1972, 1974; Wickham and others, 1978; Colman and Foster, 1990; ISGS, unpublished data) support the correlation of reflection $\mathrm{R} 2$ with the base of the gray postglacial clay. However, Wickham and others (1978, fig. 4) apparently used the stronger, deeper reflection R3 as the base of the postglacial deposits and indicate that more than $5 \mathrm{~m}$ of postglacial deposits occur in the deep basins. In contrast, using reflection R2 as the base of postglacial deposits, we measure only 2-4 m of postglacial sediment in most of the basins (fig. 19).

The southwestern region of Lake Michigan also lacks significant postglacial sediment cover (fig. 19) where seismic profiles show till exposed over much of the lake floor, overlain by patches of sand (fig. 22). Some $3.5 \mathrm{kHz}$ seismic profiles along the Illinois nearshore show deposits of the nearshore sand wedge, which generally extends offshore and feathers out within $1 \mathrm{~km}$ of shore or grades into the lower Lake Michigan Formation north of Waukegan, IL. Our seismic profiles from this large region of nondeposition support Hough's (1935) interpretation that the till bottom in this region is eroded by present-day wave and current action, which has resulted in a lag deposit over till. Sand and gravel that is eroded from the till accumulates in discontinuous bars and ridges, or is transported to the nearshore sand body (Hough, 1935). Some deposits in this region may be relict from the transgression that followed the Chippewa low level, analogous to the buried deposit between reflection R1 and the Chippewa unconformity.

\section{ACKNOWLEDGEMENTS}

We thank the captain and crew of the RV Roger B. Simons, the RV Laurentian, the RV Neecho, and the RV Neptune for their contribution to the field program. Collection of high-resolution seismic data was made possible by $D$. Nichols and K. Parolski. Participants in the seismic cruises included D. Block, J.A. Clark, G.J. Larson, J. Meers, R.N. Oldale, and J. Risch. Helpful reviews of earlier versions of this report were provided by R.N. Oldale and D. O'Leary. 


\section{REFERENCES CITED}

Colman, S.M. and Foster, D.S., 1990, Descriptions and physical properties of sediments cored in Lake Michigan: U.S. Geological Survey Open-File Report 90-478.

Colman, S.M., Jones, G.A., Forester, R.M., Foster, D.S., in press, Holocene paleoclimatic evidence and sedimentation rates from a core in southwestern Lake Michigan: Journal of Paleolimnology.

Dell, C.I., 1975, Relationships of till to bedrock in the Lake Superior region: Geology, v. 3, p. 563-564.

Drexler, C.W., Farrand, W.R., and Hughes, J.D., 1983, Correlation of Glacial Lakes in the Superior Basin with eastward discharge events from Lake Agassiz, in Teller, J.T., and Clayton, Lee, eds., Glacial Lake Agassiz: Geological Association of Canada Special Paper 26, p. 309-329.

Eadie, B.J. and Robbins, J.A., 1987, The role of particulate matter in the movement of contaminants in the Great Lakes, in Hites, R.A. and Eisenreich, S.J., eds., Sources and Fates of Aquatic Pollutants: American Chemical Society, Advances in Chemistry Series.

Emery, K.O., 1951, Bathymetric chart of Lake Michigan: Univ. of Minn., Institute of Technology, Engineering Experiment Station Technical Paper No. 77, 11 p.

Foster, D.S. and Colman, S.M., in press, Thickness and distribution of postglacial deposits in Lake Michigan: U.S. Geological Survey Miscellaneous Investigations Series Map.

Gross, D.L., Lineback, J.A., Shemp, N.F., and White, A.W., 1972, Composition of Pleistocene sediments in southern Lake Michigan, U.S.A.: International Geological Congress, 24th Session, Section 8, p. 215-222.

Hands, E.B., 1983, The Great Lakes as a test model for profile responses to sea level changes, in Komar, P.D., ed., CRC Handbook of Coastal Processes and Erosion, Boca Raton, Florida, CRC Press, Inc., p. 167-189.

Hansel, A.K., Mickelson, D.M., Schneider, A.F., and Larsen, C.E., 1985, Late Wisconsinan and Holocene history of the Lake Michigan basin, in Karrow, P.F., and Calkin, P.E., eds., Quaternary Evolution of the Great Lakes: Geological Association of Canada Special Paper 30, p. 39-53.

Hough, J.L., 1935, Bottom deposits of southern Lake Michigan: Journal of Sedimentary Petrology, v. 5, p. 57-80.

1955, Lake Chippewa, a low stage of Lake Michigan indicated by bottom sediments: Geological Society of America Bulletin, v. 66, p. 957-968.

1958, Geology of the Great Lakes: Urbana, Illinois, Univ. of Ill. Press, 313 $\mathrm{p}$.

Koteff, Carl and Pessl, Fred, Jr., 1981, Systematic ice retreat in New England: Geological Survey Professional Paper 1179, 20 p.

Larsen, C.E., 1985a, Lake level, uplift, and outlet incision, the Nipissing and Algoma Great Lakes, in Karrow, P.F., and Calkin, P.E., eds., Quaternary Evolution of the Great Lakes: Geological Association of Canada Special Paper 30, p. 63-77.

1985b, A stratigraphic study of beach features on the southwestern shore of Lake Michigan--New evidence of Holocene lake-level fluctuations: Illinois State Geological Survey Environmental Geology Notes 112, 31 p.

1987, Geologic history of glacial Lake Algonquin and the upper Great Lakes: U.S. Geological Survey Bulletin 1801, 36 p.

Lineback, J.A. and Gross, D.L., 1972, Depositional patterns, facies, and trace element accumulation in the Waukegan member of the Late Pleistocene Lake Michigan Formation in southern Lake Michigan: Illinois State Geological Survey, Environmental Geology Note No. 58, 25 p.

Lineback, J.A., Ayer, N.J., and Gross, D.L., 1970, Stratigraphy of unconsolidated sediments in the southern part of Lake Michigan: Illinois State Geological Survey, Environmental Geology Note No. 35, 35 p. 
Lineback, J.A., Gross, D.L., Meyer, R.P., and Unger, W.L., 1971, High-resolution seismic profiles and sediment cores from southern Lake Michigan: Illinois State Geological Survey, Environmental Geology Note No. 47, 32 p.

Lineback, J.A., Gross, D.L., and Meyer, R.P., 1972, Geologic cross sections derived from seismic profiles and sediment cores from southern Lake Michigan: Illinois State Geological Survey, Environmental Geology Note No. 54,44 p.

1974, Glacial tills under Lake Michigan: Illinois State Geological Survey, Environmental Geology Note No. 69, 48 p.

Lineback, J.A., Gross, D.L., and Dell, C.I., 1979, Glacial and postglacial sediments in Lakes Superior and Michigan: Geological Society of America Bulletin, Part 1, v. 90, p. 781-791.

Mitchum, R.M., Jr., Vail, P.R., and Sangree, J.B., 1977a, Seismic stratigraphy and global sea level, part 6: Stratigraphic interpretation of seismic reflection patterns in depositional sequences, in Payton, C.E., ed., Seismic stratigraphy - applications to hydrocarbon exploration: American Association of Petroleum Geologists Memoir 26, p. 117-133.

Mitchum, R.M., Jr., Vail, P.R., and Thompson, S., III, 1977b, Seismic stratigraphy and global sea level, part 2: the depositional sequence as a basic unit for stratigraphic analysis, in Payton, C.E., ed., Seismic stratigraphy applications to hydrocarbon exploration: American Association of Petroleum Geologists Memoir 26, p. 53-62.

National Geophysical Data Center, 1987, NOS hydrographic data base - expanded digital bathymetric data for coastal waters: NOAA National Geophysical Data Center Data Announcement 87-MGG-12, 8 p.

Sly, P.G. and Thomas, R.L., 1974, Review of geological research as it relates to an understanding of Great Lakes limnology: J. Fish Res. Board Can., v. 31, p. 795-825.

Teller, J.T., 1985, Glacial Lake Agassiz and its influence on the Great Lakes, in Karrow, P.F. and Calkin, P.E., eds., Quaternary evolution of the Great Lakes: Geological Association of Canada Special Paper 30, p. 1-16.

Thwaites, F.T., 1949, Geomorphology of the basin of Lake Michigan: Michigan Academy of Science, Art, Letters, v. 33, p. 243-251.

Wickham, J.T., Gross, D.L., Lineback, J.A., and Thomas, R.L., 1978, Late Quaternary sediments of Lake Michigan: Illinois State Geological Survey, Environmental Geology Note No. 84, 26 p.

Willman, H.B. and Frye, J.C., 1970, Pleistocene stratigraphy of Illinois: Illinois Geological Survey Bulletin 94, 204 p. 